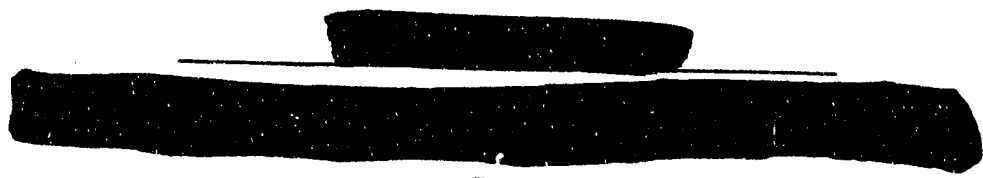

HW--30401-Vol.1

GENERAL GLETRIC

DE93 006706

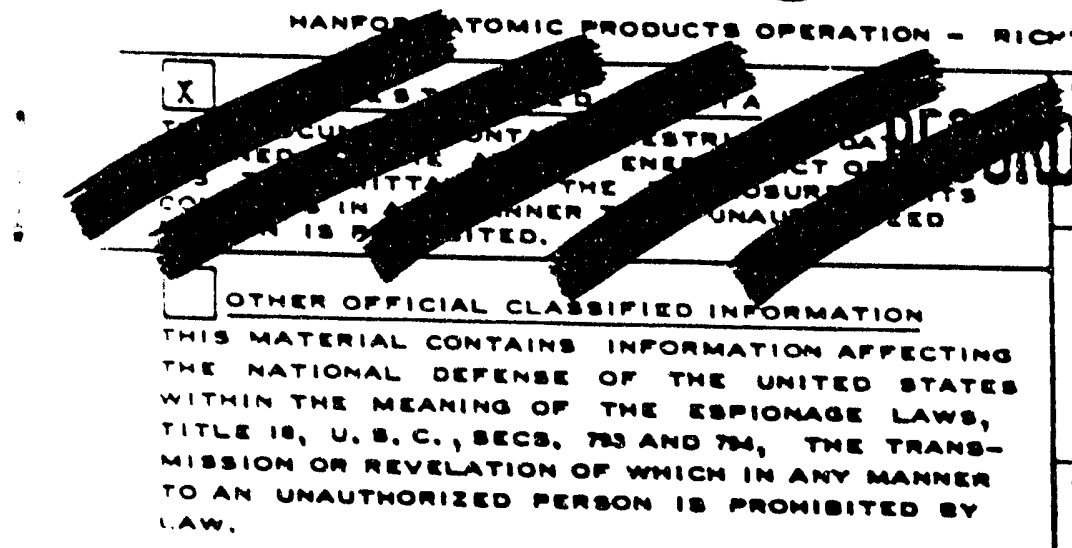

\title{
CENTER FIIE
}

TITLE

DESIGK CR TTERIA-RINCFCR FLANT

MODIFICAFIONS FOR IRCRZUSBD PRODUC:

AND ION-C AREA NIEZUTITORS

SECTIONS A AND B A

$C G-558$

Nit

M. B. RUSS

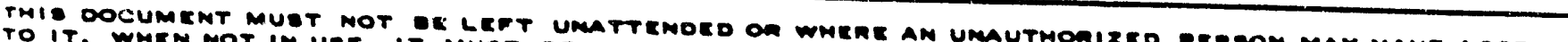

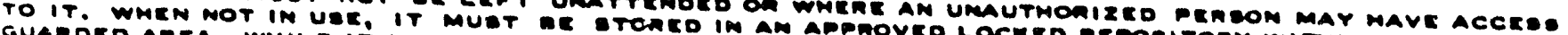

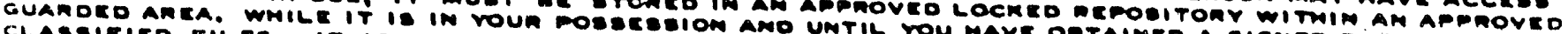

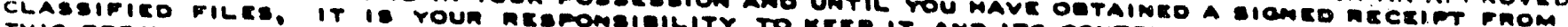

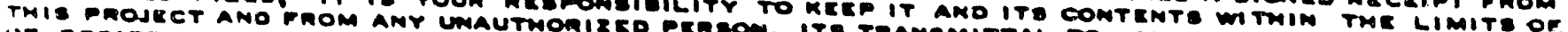

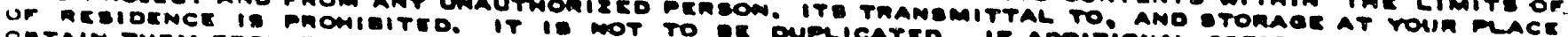

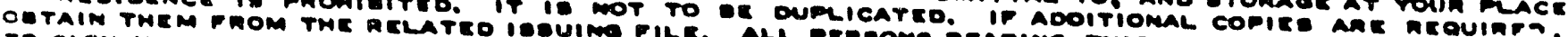

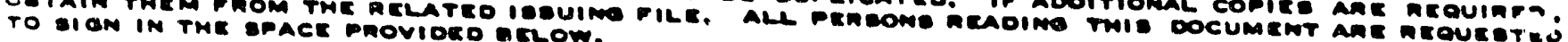

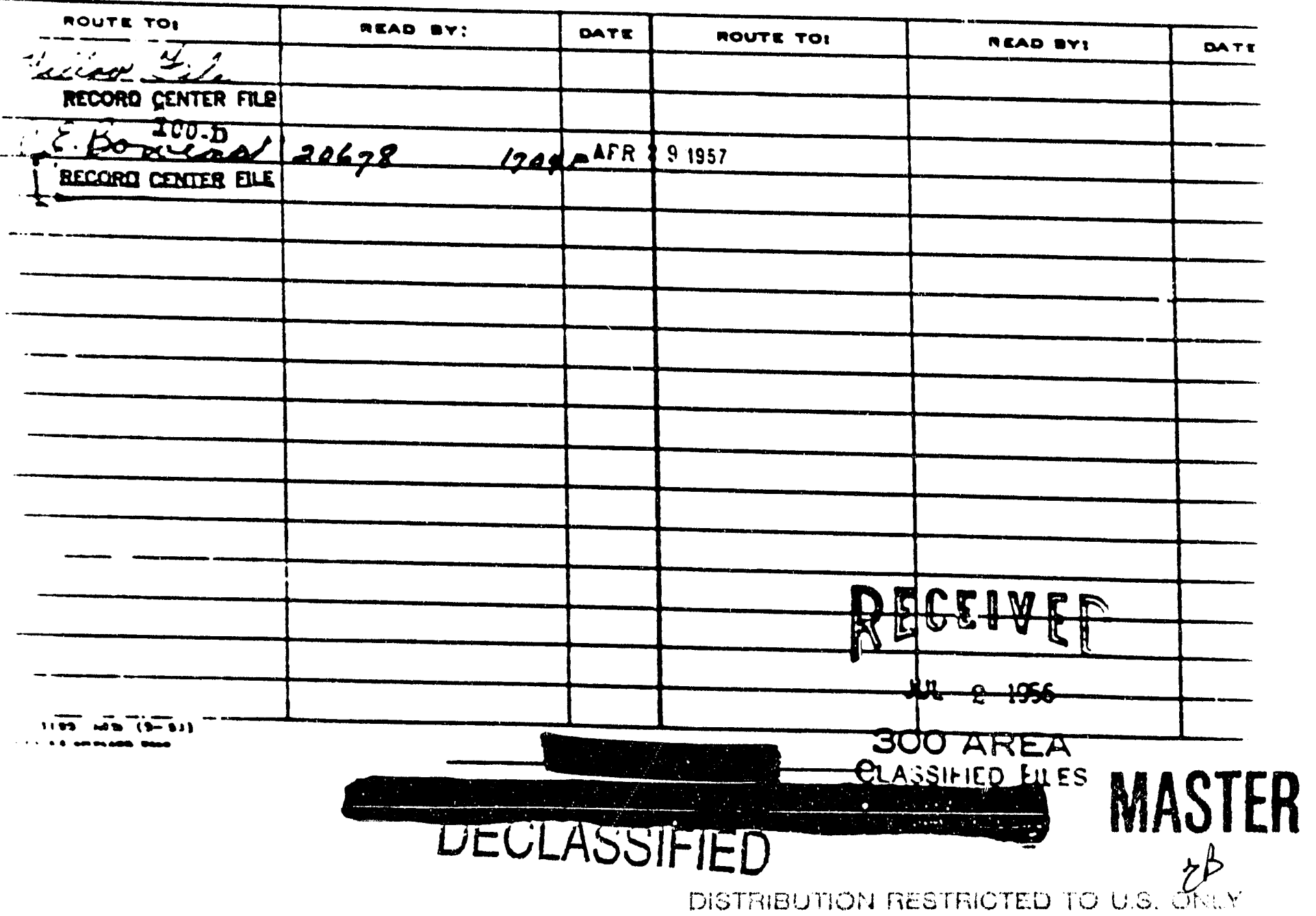




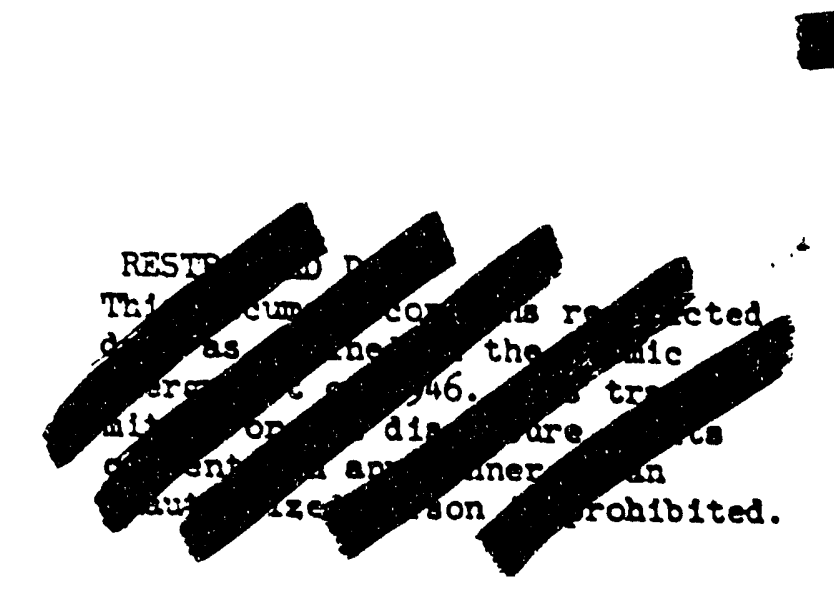

EW-30401-Vol. 1

Page 1

copy 1 of 1, seming

Mh1s document cons1sts of

pages. Copy No.

cop1es. Ser1es tr

AUG 101954

Apes 2 2, 25

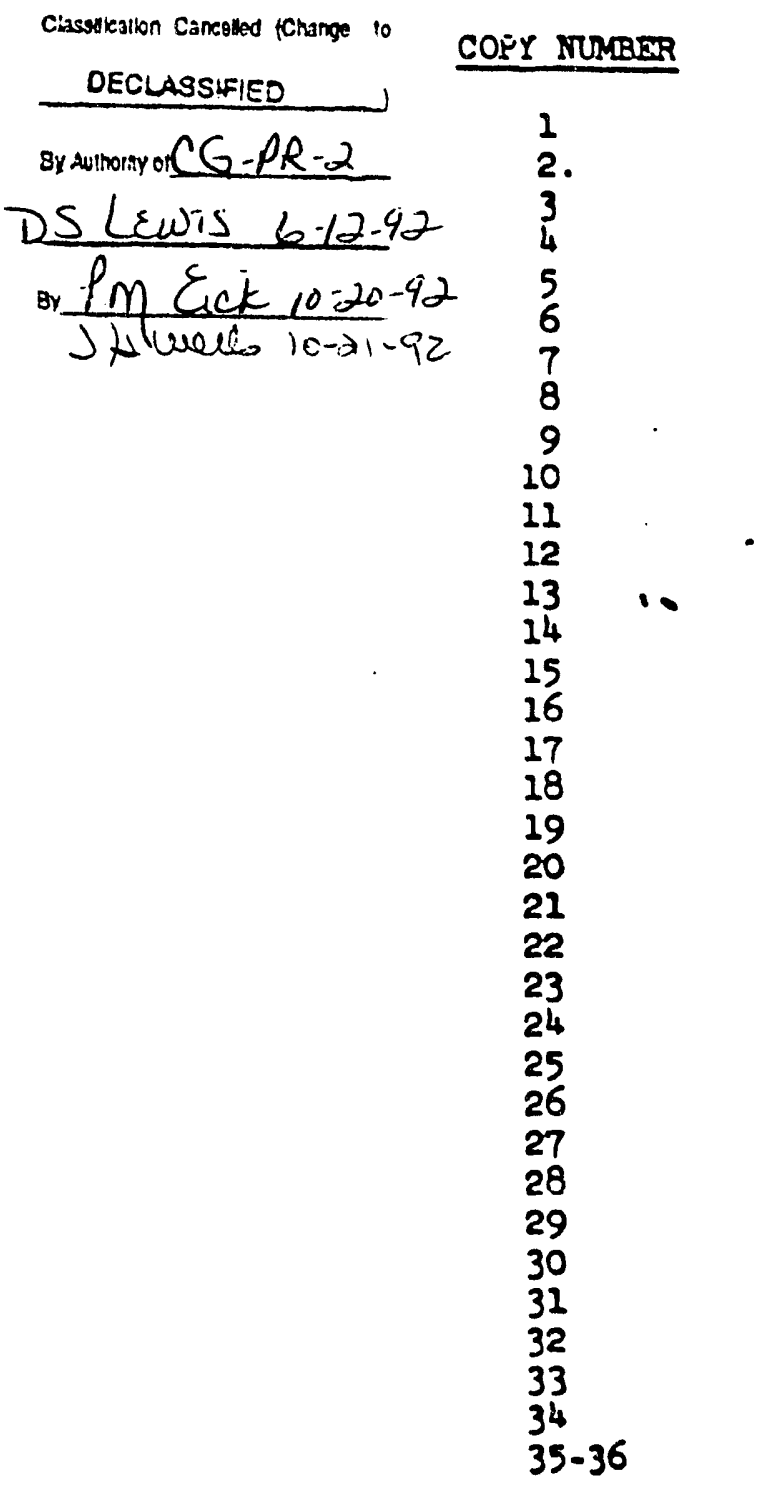

DISTR IBUTION

H. X. Alexander

R. K. Andereen

O. B. Beuer

R. B. Benton

C. R. Bergatal

J. I. Boyd

B. A. Caribers

W. J. Dow1s

H. F. Caretson

O. B. Greager

A. B. Oreninger

T. W. Baurs

J. M. Beffaes

R. B. Bubble

B. M. Johnetan

W. K. MacCreadr

J. C. Mclaughl 1 a

J. 3. Mckahon

J. B. Maider

R. O. Mebana

O. B. P1Lres

P. B. Reinter

R. B. R1cbarde

M. B. Ruse

B. P. Sbav

J. M. 8n1tb, Jx.

F.A.R. 8talatea

J. I. Jhowes

J. B. Warsoo

B. T. Hells

J. R. Holcott

H. B. Hoode

Ielion $P 110$ $300 \mathrm{P110}$

Dxtro 
DECLASSIFIED

Volune I

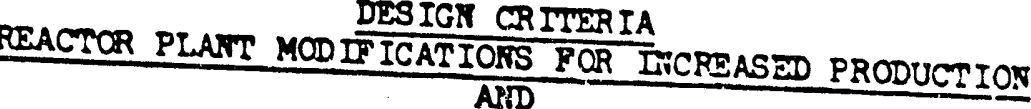
100-C ARE APD ALTERATIONS

Reactor Disign and Development Unit Process Inglneer1ng Sub-Section General Electr1c Company - Banford Atomlc Froducts

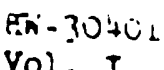

Yol. I Prepared by HA Nexpes

Date_Apr11 2, 2554

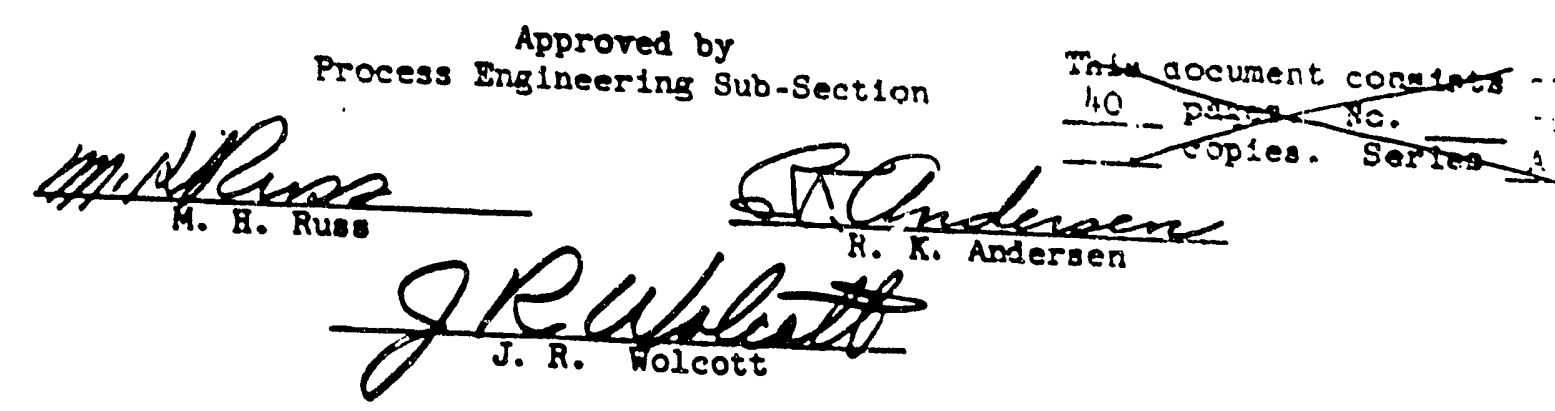

DESIGI PROJECT CG-558 REPRESEATATIVES

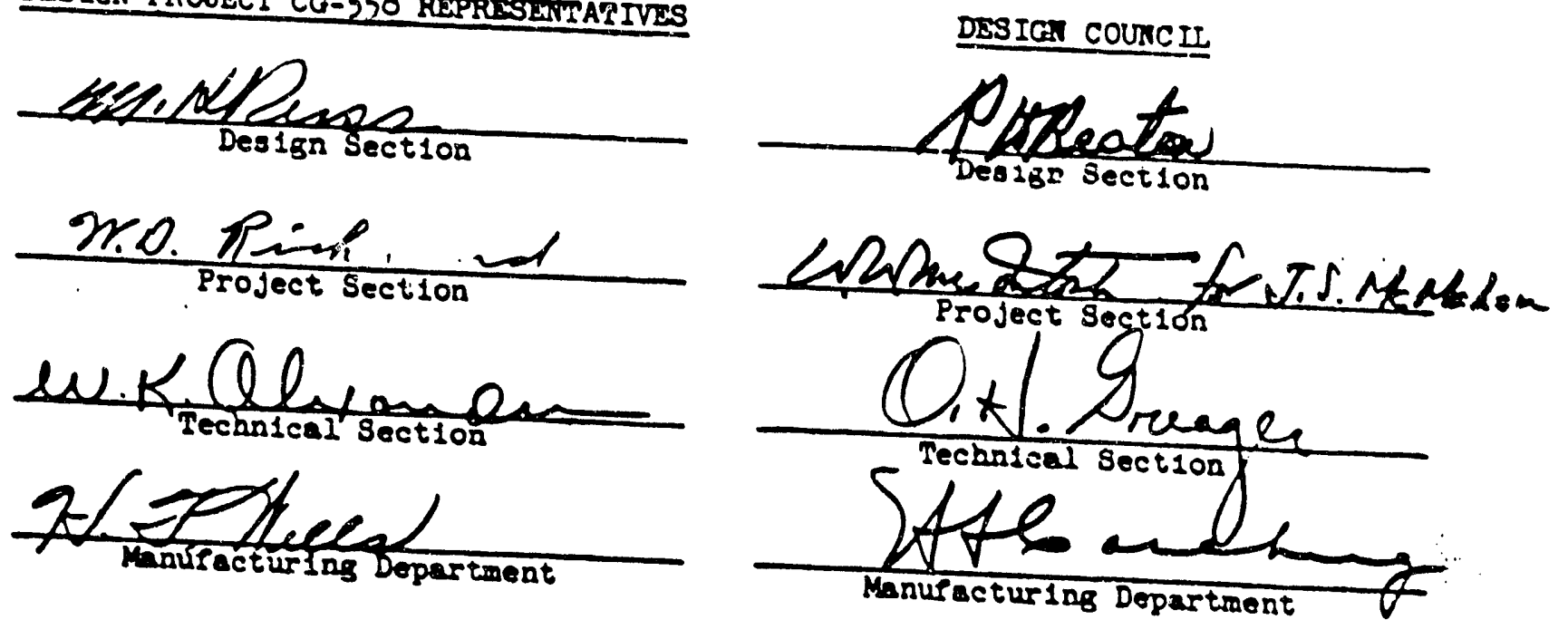

ATOMIC Erstor Camies ION

artelinpes 
IESIGN CRITERTA

FEACTOR PLAITT WODIFICATION - PROJECT CO-558

TABRE OS CONTRY IS

SECTION A

QENDERAL

Introduction

Purpose

Organ1zat1on of Document

SECTION B

$200 \mathrm{~B}_{2} \mathrm{C}$ AREA NODIFICATIONS

I. RASIC DESIGN REQUIREMENTS

1. mo Introduction

1.100 100-B Area

1.120 Reactor coolant and subasdiary Water hequscoments

1.111 Quant1tative

1.112 jealltat1ve

1.123 Buergency Shutdown

1.124 Filtered Water Storage

1.120 Conversion fram Stcam Pover

1.2.30 Reactor P1p1ng

1.140 Disposal of Reactor Ersluent 11

1.250 Instrumatat1on and Control 11

1.260 Cont1mous Po1son Colum Chargins

1.170 8paro Bydraulic Capac1ty Carg1as 12

1.280 Arebltecture Capec1ty 12

1.181 Ceneral

1.182 8tructural Des180 22

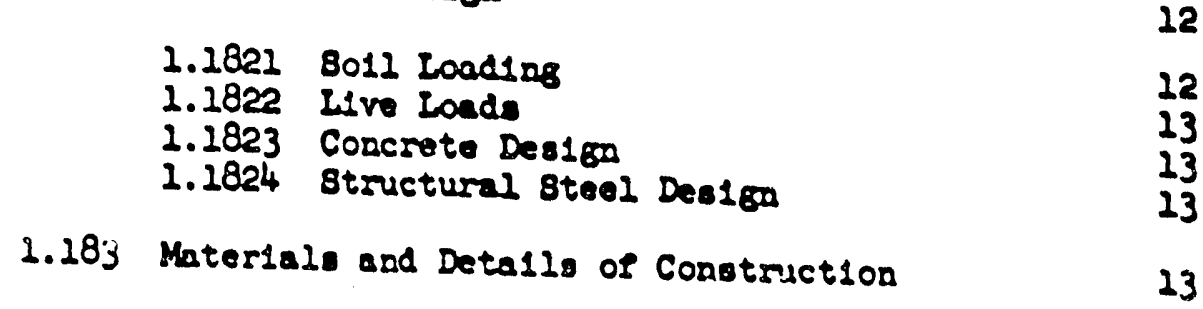

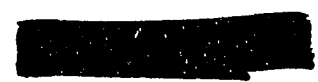




\section{DECLASSIFIED}

1.184 Acoust1cal Treatment

1.185 Beating and Ventilation

$1.200 \quad 100-c$ Area

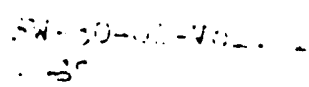

1.210 Resctor Coolant

1.211 Quant1tat1ve

1.212 Qualitative

1.213 Emergency Shutdown

1.214 Filtered Water Storage

1.220 Reactor P1pling

1.230 D1sposal of Reactor Effluent

1.240 Instrumentation and Control

1.250 Cont1nuous Polson Column Cha

2.260 Spare Hydraul1c Capac1ty

II. BASIC DESIGN PHIIOSORHY

2.000 Introduct1on

2.100 100-B Area

2.210 Reactor Mod1f1cations

2.111 Front Face P1ping

2.12 Instrumentat10n

2.1121 Tube Presourn Mon1tor1ns

2.1122 Blolnelcal Shield, Terperaturs

2. 2223 Monttoring

2.1124

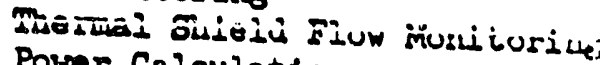

2.1125

Power Calculation

2.113 Poison Columa Charging Mochan18u

2.114 Bor1zontal Rods and Trimbles
2.215 Downcomers

2.120 Process Water System

2.121 Procese Wator P1p1ng

2.122 Process Water Pumplas

28

2.130 F11tered Sol1ds Feed 8yatea

2.131 Wator Treatront

2.132 Pliter Plant 


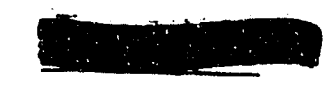

BW -30401-VOI. I Page

\subsection{Fissh Mix1ng Chambers \\ 2.1322 F1lter Insluent Flume \\ 2.1323 Filter Bed \\ 2.1324 Filter Effluent Flume \\ 2.1325 Clearwater Reservo1r \\ 2.1326 Filtar Flow Controllers}

\begin{tabular}{r} 
Pase \\
\hline 30 \\
31 \\
31 \\
31 \\
31 \\
31
\end{tabular}

2.133 Filtered Water Punping

2.134 Filtered Water P1pe IInes

2.135 Flltered Water Storage

31

32

2.140 Raw Water System

2.150 Electric Power Supply

2.160 Steam Generation and Ut1lization

2.170 P1le Effluent System

2.171 Procesa 8ever System

2.172 107-B Retention Basin

2.173 Outfall Syatem - 107-B to M1d-River Channel

2.200 100-C Area

2.210 Reactor Modiflcat1ons

2.211 Front Face Piping

2.212 Instrumentation

2.213 Polson Colum Charging Mechan1am

2.200 Procege Watar gyatem

2. 230 Filtered Water Sybtem

2.231 Water Treatment

2.232 Filter Plant

2.233 Filtered Water Pumping

2.240 Raw Water System

2.250 Electric Power Supply

2.270 Reactor Effluent 8ystem

2.271 Process Sever system

2.272 107-C Retent10n Bas1n 


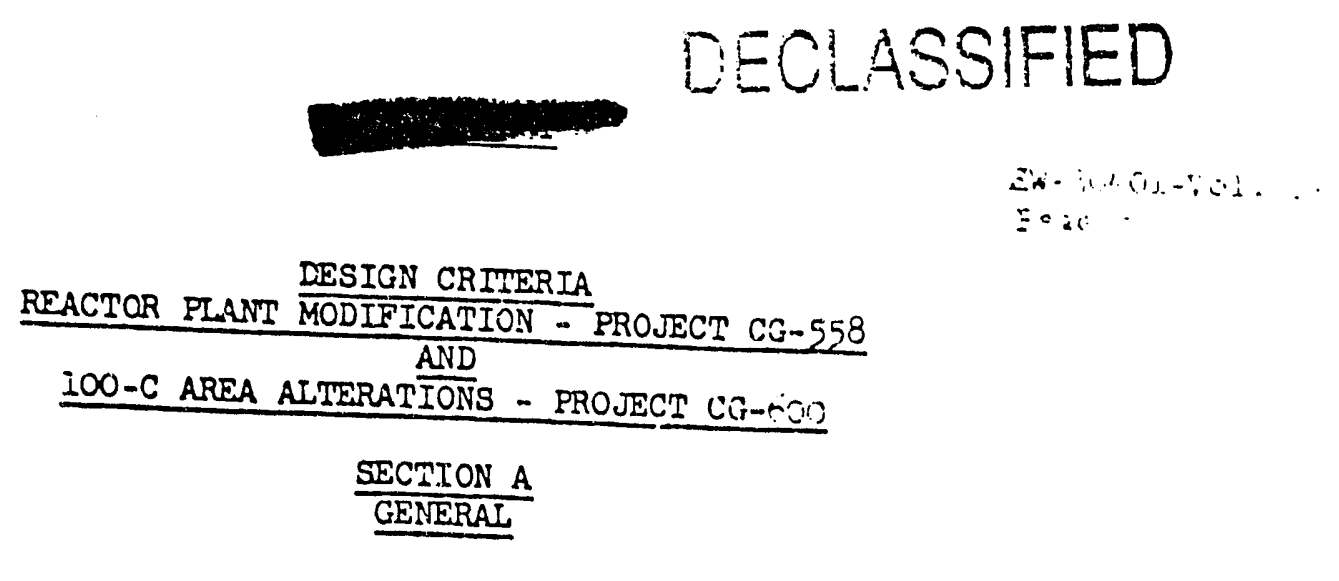

INTRODUCTION

This document defines the basic criteria to be used in the prepararion of retsided and for Project CG-600, 100-C Area Alterations. most economical metnod of increasing plutonium. It has been determined that the years is by the modernization and 1mprovement production within the next iive $100-F$, and 100-H reactor plants. These reactor the $10 C-B, 10 \%-C, 100-D$, $100 .$. Dr, ting at their maxlmum potential power levelo because errently 1ncapabis of upuraprocess cooling water. As a result of thels because or a ilini:ad avalisbiltt. or 2350 megaratts of total additlonal production uilum, it is estimatad tims $1650-$

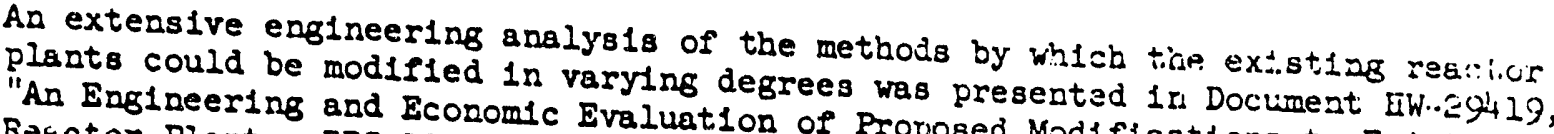
Reactor Plants, RDS-10 and RDS-11", dated Septemed Modifications to Ixistlris more important alternates 18 presented in tive Cases for Project CG-558", dated In Document HW-29707, "Summary of Alternato D. F. Shaw, "Alternat1ve Capacity Increases 21, 1953. In a letter, W. E. Johrasor. 21, 1953, the Commission was reçliested to appra1se thoject CG-558", dateid October ion increases in the light of their anticluation the aiternate cases cif producD. title (Document BAN-52827) dated November P. Shaw tc W. B. Johnson of the same achlevement of the maximum product1ember 27, 1953 in which they stated that the modiflcations (Case Seven) at action potential represented by ti:e rroposer to the Commission's program.

\section{PURPOST}

The purpose of this document is to set forth the design basis for certein modif1cations and add1tions to Banford reactors and thels supporting fuclilties as t1on.

The objective in making these changes to exist1ng fac1lities is to ralse the proand 105-B; to obtaln more efflclent ut1112at10 , 105-C, 105-D, 205-DR, 105-F, city; and to add to the safety of reactor operation.

The bases for mgor decislons regarding the type of 1nstmumentation, fower transand safety conslderstions are contalned jor equipont and other tecbnicul, ecozosic,

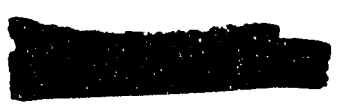


HH-30401-VOL. I$\because$ Dagd 7

Th? portion of this document following this Section A is dilded 1ato s1x major $s:=$ t1ons cestgnated "B" through "F".

Son:tions B, C, D, and E define the modifications to be made to Areas 100-B, C; $100-D$, IR; $1 X:-B$; and $100-F$, respect1vely. Section $Z$ contalns the codes and standards that milst he otserved in the des1gn covered by th1s document, and the reference docunurits upon which these criterla are based.

Eart sicceeding section except section $P$ is divided lato three parts. Part I cietines the basic requirements that mat be fulfilled in the redesign of the systam. Part II defines the phys1cal changes to the ex1st1ng system wh1ch mast be mande in order to meat the requirements of operab1lity and safety defined 1n Part I. Part. III wII be issued subsequently as a revision or addendum and w1ll define in jetalled and specific terms the nature of the alterations to system components sisch as pipling and structures, and the nature of nev equipment and processes.

Ali modifications that are to be made to i00-C Area will be under Project IN-C Area Alterations, except that the secondary pressure monftoring system for' 1C5-C w117 be part of Project CG-558, Reactor Plant Modifications. 


\section{DECLASSIFIED}

\section{0 \\ SECTIOR 3 \\ 100-B, C AREA MODIFICATICX}

\section{$\therefore$ BASIC DESIGN REQUIREMETTS}

\subsection{Introduct10n}

Part I of this section 1s latended to set forth ficw ard quality =o: quirements of the water required to support tye rea.tor fower lere: objectives; establish required forgrovements for safajy ard raital: l:ty;

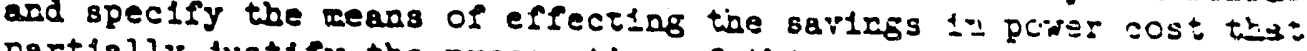
partially Justify the prosecuticn o: this program.

\section{$1.100 \quad 100-$ B Area}

1.110 Reactor Coolant and Subsidiary Water Fequiremezts

1.111 The basic continuous quantities of watar to be provided are as follows:

To process
To export
Ron-process to 105-B
Miscellaneous

$7: 000$ 5p0
18,000 50:
4,200 500
1,500 8p0

The total amounts of raw and f1ltered water to be handled are derived under the descriptior of the varlous component parts of the plant contalned i= Farts II and III of this document.

1.212 The quallty of coollag xater furnlshed to the reactar aball weet the following speifications:

Turb1d1ty.................20 ppE nax1mur Iron...................0.03 ppw max1mum Aluminum..................50 ppr maximus Chlor1des.................2.00 ppa mextmum PH...................... 7.5 to 7.8 Bodlum Dichromate...........2 1 I ppa at ung ting Tree cblorine............... p.2 ppe exdmus

\section{tar}

1.113 Onder the cond1tion of an emergency shutdown prec1p 1 tived by the BPA porer fallure, vater shall continue to be do livered to the reactor without interruptian. It sbilingei dellvered at a rate such that the top of Flser preasures aball docay at a rate, $r$ th resfect to 1100 after pordy fallare, not greater than that shown on Exhlbit 1. 1131 ".

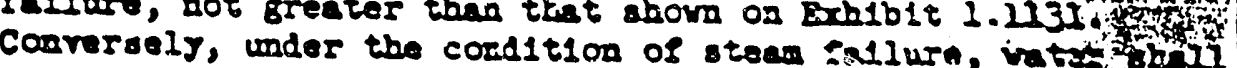

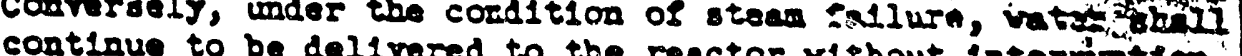

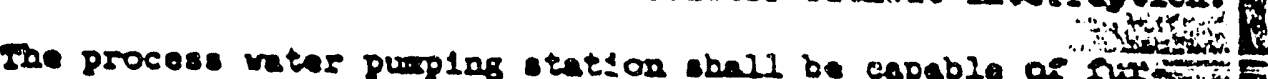

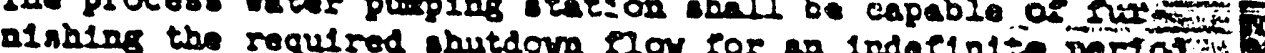
$0:$ time vithout bour on sxilo1t 1.1132 . 
VARLATION OF REQUIIRED TORP

AFTER BPA UUTAGE

IO5-B REACTOR

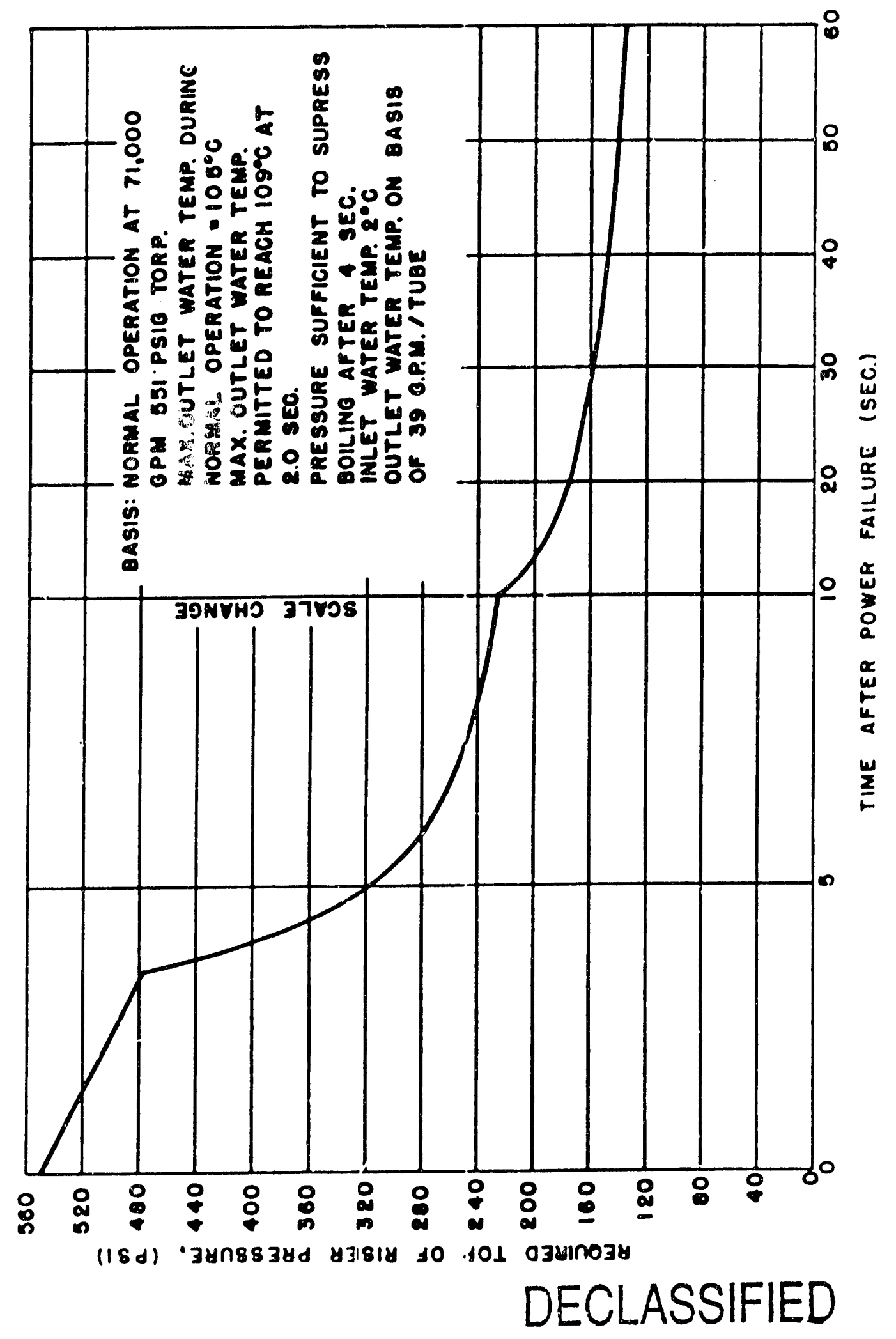




\section{DECLASSIFIED}

\section{Exing 1.2132}

BN-30401-701. I-

Ine 10

-

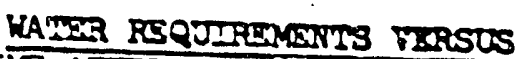

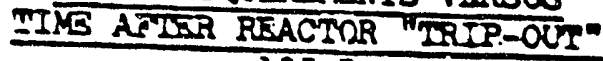

$105-8$

\begin{tabular}{|c|c|c|}
\hline \multicolumn{3}{|c|}{ PמA } \\
\hline Ers. & $\underline{x}$. & Se: \\
\hline 0 & 30 & 0 \\
\hline 0 & 30 & 10 \\
\hline 0 & 30 & 32 \\
\hline 0 & 32 & 0 \\
\hline 0 & 32 & 0 \\
\hline 0 & 33 & 0 \\
\hline 0 & 34 & 0 \\
\hline 0 & 35 & 0 \\
\hline 0 & 40 & 0 \\
\hline 0 & $x^{7}$ & 0 \\
\hline$\therefore$ & 5o & 0 \\
\hline$c$ & & \\
\hline 1 & 35 & 0 \\
\hline 2 & 30 & $c$ \\
\hline 3 & 30 & 0 \\
\hline 4 & 30 & 0 \\
\hline 5 & 30 & C \\
\hline 6 & 30 & 0 \\
\hline 30 & 30 & 0 \\
\hline
\end{tabular}

\begin{tabular}{cc}
$\begin{array}{c}\Delta \text { mine } \\
\text { Rinutis }\end{array}$ & $\begin{array}{c}\text { Arerage } \\
\text { Now } \\
\text { GPM }\end{array}$ \\
\hline 30 & $7,, \infty 00$ \\
$1 / 6$ & $62, \infty 00$ \\
$1 / 3$ & $41, \infty 00$ \\
1,2 & $36, \infty 00$ \\
1 & $32, \infty 00$ \\
1 & $28, \infty 00$ \\
1 & $28, \infty 00$ \\
1 & $28, \infty 00$ \\
5 & $27, \infty 00$ \\
10 & $25, \infty 0$ \\
10 & $23, \infty 0$
\end{tabular}

For Dur1ss

Persod

Gallons

$2,130,000$.

10,000

24,000

28,000

32,000

$28, \infty 00$

28,000

28,000

235,000

250,000

230,000

30

21,, 00

630,000

60

28,500

$1 ; 110,000$

60

23,400

$004, \infty 00$

60

8,800

5,700

528,000

342,000

60

3,600

216,000

1,40

2,880

sesear.

$4,147,000$

$30,600,000$

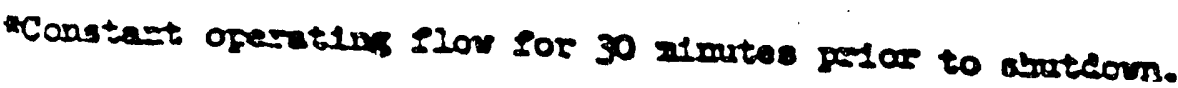




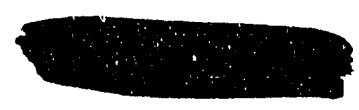

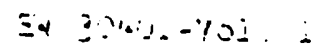

Pape 11

i.114 There sball be surpiclent p1ltered vates otorad asd ava:Iable to the reactor, vithout repleniskment sad the rav vater aystem, to provide 30 riclices of normal procoss trans plus the rolume required to satisfy the exerzency of sbutdowa flow.

1.120 Converston fror steam pore:

The present systew of process water punalas, whereby approxlastely sos of the total porer required is riralsted by sieas turicices, continue to be aretlable all electrtc systea. Siean pover stail required pumplavg loable. It ball autocat:sally assume the

1.130 Reactor P1p1ng The pressure at the lalet of any trresso tuhe skell not excesd
450 p818.

The front face crossheaders abail be sod:fled to provide a check valve at each end of each crossheader, as protection agalnst the effects of earthquake or bumb blast

1.140 D1sposel of Reactor Effluent

The reactor effluent sball be retalned for an average t1me of not less than one hour before belng discharged 1nto the Collumin

1.150 Instrumentation and Control

All lastrumentation shall be of surpicient range and strength to perforn 1ts hunstion under the condltions resultiag srom this
prouram.

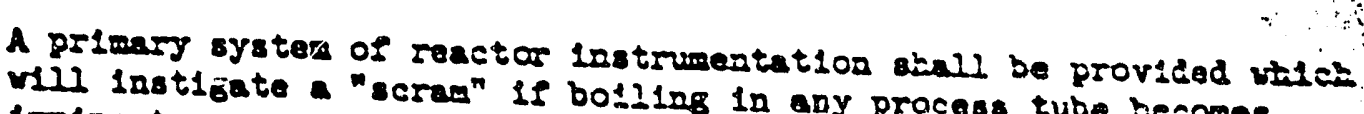
Imoninent.

A secondary systes $0:$ reactor lastrumencation aball be prorided whlch vil "backup" the prlmary aysten to the extent that the dentingace of bolling in anj process tube v1ll be detected Indepeninitiatod.

A torperature nonstorlas grated shall be provided to peralt and top bloloteralnation in each laver of Misoslte of the side rete.

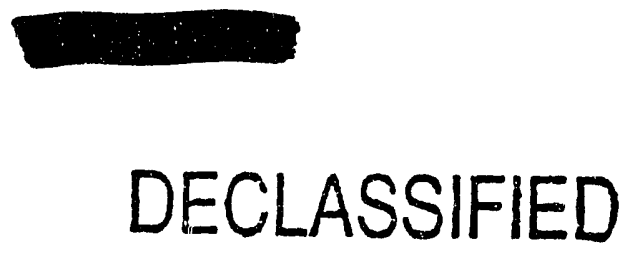




\section{DECLASSIFIED}

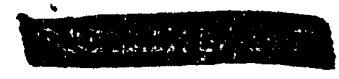

ENA-30401-Vol. 1

Page 12

A Ilow 1adicat1as systen shall be provlded to permit the positive

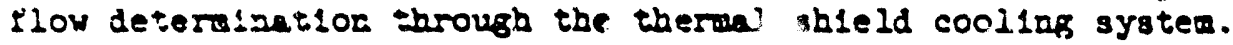

The cala grocess rater punp aotors and thelr discharge pressures stall te controlled erce a central control otation in the 190-B Bulidiss.

The borlzcatal control rods, thelr thimbies, ard test bole thimbles stall be mod1s1ed or replaced to withstand the blgher temperatures, ald other corditlons ar1siag from th1s program that would be 1nimlra: to rod operation.

$\therefore .100$ Cont12ucus Polsor Columan Charg1ng

Siltakle reckacion shall be provided to enable certaln process tubes $: 0$ te charged of d1scharged w1th "po180n" slugs w1thout shutt1ag dowe the resctor. Sub nechan1sm abul not preclude the opt1on of chargias the sase tubes irth suel slugs during shutdown.

1.270 Spare Eydraui1c Capac1ty

Oze spare unit akall be provided at every pumping station furnish12f vater to the riltes plant or to process.

\section{180 A-chitecture}

\subsection{Gereral}

The guldice ph1losophy wh1ch aball be used to deteralne the ershitectural deslige sall be that the plant stluctures are to be designed on a functlonal basis w1th no architectural sreateent for purposes of appenrance.

\subsection{Structurel Desige}

All atructures ball be deslgaed to w1thstand the londs Bfecifled belov vithout exceeding otresses or comblantions of stresses es ipecifled hereinafter or as provided in Section I of this docment.

\subsection{So11 Loadirs}

Desion malues for soll bearlas abnll be in accordance inth the ralues glrer by the Unifora Bullalng Code for compect 11 ur. canc'. In no cese shall the soll bearlog preseñ areeed 8000 pounds per aquare foot. Fowndations placed adjacent to and above the lerel of the botton of deep rerticel muls abnl be placed on a leas conerete bacte111. In no case stell footlngs be placed on bectellled earth. I1II placed arring the construction of the orfelnal plant atul not be constsxred as backe1ll. 
Earthquake loads sholl be of an Intersity spec1pied.

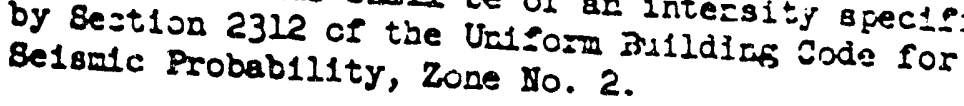

Roor loads eball de saken as a unlformly dist.ribute? load of 25 pounds per square foot of root area projected on a horlzontal plaze.

Ploor and plat:orm loaks the1r usage and erestor cond be established by Wind loads ohall be tak

buted borlizontal be taken as a vafformly distriacting on the vert1cel profertion per square soot

1.1823 Concrete Design

Relaforced concrete desion shali be in accordance with the requirements of the "Building Code Requizeused shall be tbose specifete" (ACI-318-51). Stresses crete itich will develop an ultion structural conof 3000731 .

\subsection{Structural 8tecl Deslgn}

8tiructural ofeel desion shall be 1.n acsortaces with the requirement of the AISC "Specleication for the Bteel for Bulldings". and Proction of stmint.2?? shall be desloned ". In Bener.l, brillelas srases - tructural cont1mutty cont1suous atrictures and of velding or Ierdelet bolts acbleved iy the use vil be permitted.

\subsection{Kater1als and Deta118 of Cosstruction}

Al bullding housing operat1s personsel acd equipoedt

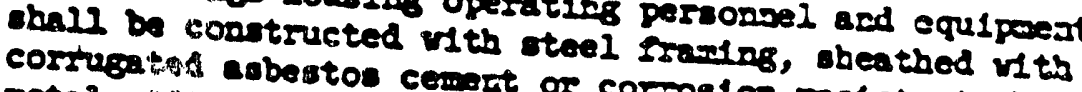
potal indsyg. To burabit or corrosion rasiatant skect

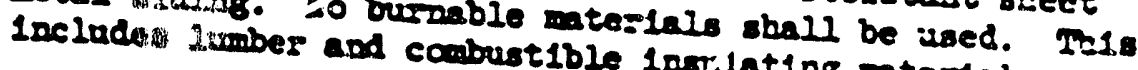

-ball bo latermediato relaforeed concrete construct1on qus rements of "Btapdard 8pon1fl shall conform to the rs-

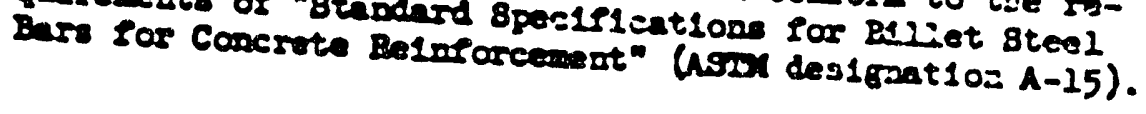

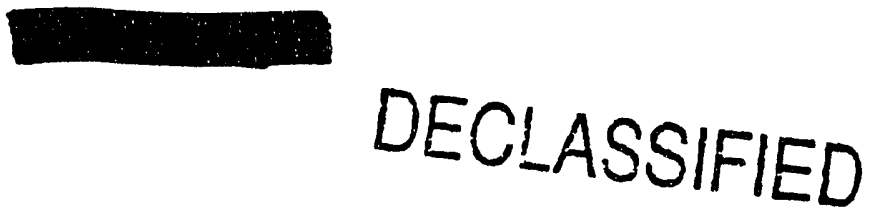


EN-30401 - Voi. 1

Page 14

Reinforcting bars shall be deformed in accordance with ASTM deslera:1inn A-305.

All roo:s sall be adequately sloped to provide dralpage. Ruof slakg stall be reinforced gypsum or poured in place

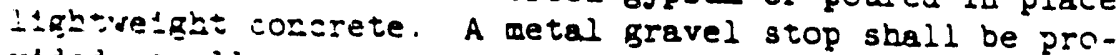
vidat at bll eaves. Metal gutters and downcouts sball be provided only where water would splil on lower roofs or cier dicrays and walks. All roofs sball be covered $\because 1$ th a 20 -year bullt up asphalt meabrace covered with grave?.

Flones siall be relnforced concrete except steel grating will be used where required over valve pits, pipe gallerles,
ets.

Statrs stal: be fajricated of (1) steel chancel stringers with steel grating treads or concrete fllied pan type treads or (2) poured reinforced concrete. Guard rall1ngs shall be stael of the "Nu-Ra1l" type, or 1ts equivalent. 


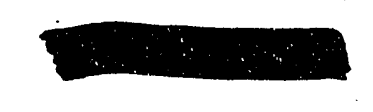

$$
\because-5 \div
$$

No Windows shall be provided in any exterta. aill. Interlor doors sball be ce the bollow satal type witz stael
frames.

Exterlor doors for the passage of personze: scall je of the oteel 1ndustrial type with shoriel Prames. Extertor docrs for the passage of large equipres: stali js of tire noter operated rolling steel type.

1.184 Acoust1cal Treatzent

The solse level in structures modifled under this progres shall be suppressed to the practical alnimum. The des:gn of 1nternal piping, interlor finfsh ant squipmed :ourda t1ons shall be upon this basis.

\subsection{Beating and Ventilation}

Beating, cooling and rentilation systems siall of provided for major bulldings and annexes constructed under this program and where required because cf additional head load. The systems shall be designed for the following conditions:

Sumer

$$
\begin{aligned}
& \text { Outs1de Ins1de (5' abcre Ploor) } \\
& 105^{\circ} \mathrm{DB} \quad 85^{\circ} \mathrm{DB} \text { (All equiprast } \\
& 68^{\circ}: \overline{\text { ND }}
\end{aligned}
$$

\section{Hinter}

$$
\frac{\text { Outside }}{-10^{\circ} \mathrm{DB}}
$$

$I=012=$ $70^{\circ} \mathrm{DS}$ (80 equipmezt serstand

\section{Teuperatures are in degrees Fabrerhe1t.}

The rent1lstion systems shall be capable c: discharging alr through the plpe twowels to the 105 Buildins at a veloctis of 75 feet per alnute and ball be sufslclent to prevent Infiltration of dust into the buildings. 


\section{DECLASSIFIED}

EW-304()1- Vol: :

Hn: : i6

$1.200 \quad 100-C$ Area

1.210 Reactor Coolant and Subsidiary Water Requirements

1.21 The basic continuous quantities of water to be provided are as follows:

D1scharge from 190-C Process Pumps

Non-Process to 105-C

Miscellaneous

$$
\begin{array}{r}
91,000 \mathrm{gpm} \\
4,000 \mathrm{gpm} \\
1,500 \mathrm{gpm}
\end{array}
$$

The total amounts of raw and elltered water to be handled

are derlved under the description of the rarious component parts of the plant contalned in Parts II and III of this document.

\begin{tabular}{|c|c|}
\hline $\begin{array}{l}\text { Turbldity } \\
\text { Iron } \\
\text { Aluminum } \\
\text { Chlorides } \\
\text { pH } \\
\text { Free Chlorlne } \\
\text { Sodium Dlchromate }\end{array}$ & $\begin{array}{l}0.20 \text { ppm maximimm } \\
0.03 \text { ppm maximim } \\
0.5 \text { ppm maximim } \\
2.00 \text { ppm maximum } \\
7.5 \text { t.0 } 7.8 \\
0.2 \text { ppm maximum } \\
2.1 \text { ppm at ang t1mu. } \\
24 \text { hour average } 2 \cdot 0.2 \text { ppm }\end{array}$ \\
\hline
\end{tabular}

1.212 The quality of cooling water furnlsbed to the reactor shall meet the folloving apeciflcations:

1.213 Inder the condlt by BPA power fallure, water ohall continue to be delivered to the reactor without 1ntersuption. It shall be delivered at a rate such that the top of riser pressure sball decay at a rate, with respect to time after power fallure, not greater than that shown on exhib1t 1.2131.

The process water pumplas station shall be capable of furnishing the required shutdown flow for an inderintte period of time without recourse to BPA power.

The water requirement versus time after reactor trlp-out 1s shown on exbib1t 1.2132 . 
VAKIAIION CIF REJUIIZED TORP

VOLU6

AFTER BPA OUTAGE

PAGE

\section{5-C REACTOR}

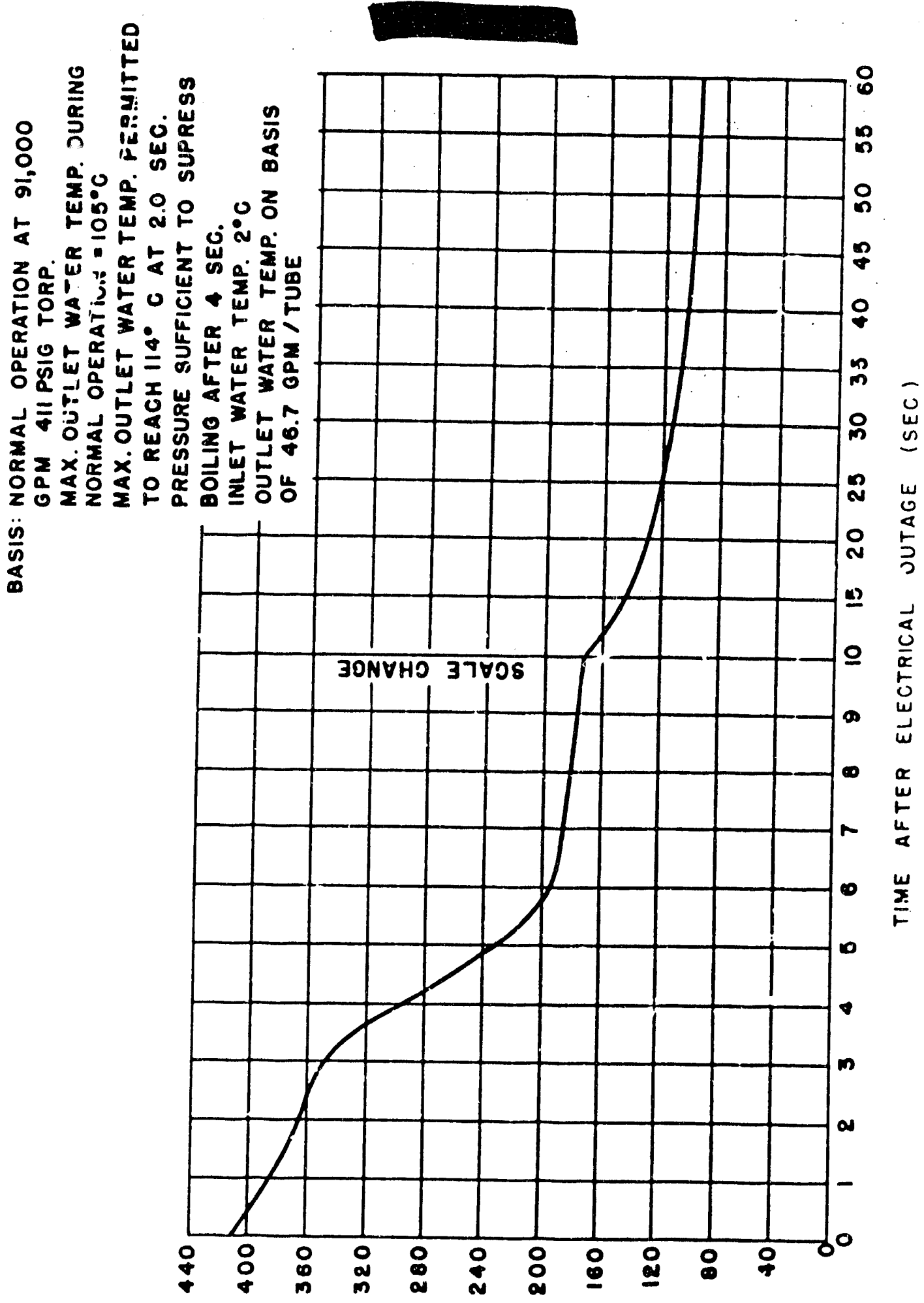

(ग15d) zynsszyd yzsiy to dol ojyinozy 


\section{DECLASSIFIED}

\begin{tabular}{|c|c|c|c|c|c|}
\hline & & TIEAT & $\begin{array}{l}\text { XXEIBIT I } \\
\frac{\text { EQUIREME }}{\text { REACTO }} \\
\frac{105-C}{\text { RE }}\end{array}$ & $\begin{array}{l}\frac{2132}{\text { TS VERSLS }} \\
\text { "IRIP-OLT" }\end{array}$ & \\
\hline Ers. & $\frac{\mathrm{TH}=}{\mathrm{M} \mathrm{n} .}$ & $\sec _{0}$ & $\begin{array}{r}\Delta \text { TIme } \\
\text { Minutes }\end{array}$ & $\begin{array}{l}\text { Average Flow } \\
\text { GPM } \\
\end{array}$ & 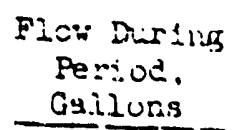 \\
\hline & 30 & 0 & 30 & $92, \infty 00$ & $2,730,200 *$ \\
\hline & 30 & 10 & $1 / 6$ & 80,000 & 13,000 \\
\hline & 30 & 30 & $1 / 3$ & 47,300 & 15,800 \\
\hline & 32 & 0 & $1 / 2$ & $40, \infty 00$ & $x, \infty<0$ \\
\hline & 32 & 0 & 1 & 34,600 & $3 \div, \infty 00$ \\
\hline & 33 & 0 & 1 & 30,500 & 30,500 \\
\hline & 34 & 0 & 1 & $30, \infty 00$ & 30,000 \\
\hline & 35 & 0 & 1 & 29,600 & 29,600 \\
\hline & 40 & 0 & 5 & 28,200 & $1+1,000$ \\
\hline & 50 & 0 & 10 & 25,900 & 259,000 \\
\hline & 60 & 0 & 10 & 23,700 & $8: 37,000$ \\
\hline 1 & 30 & 0 & 30 & 21,000 & 654,000 \\
\hline 2 & 30 & 0 & 60 & 19,100 & $1,146, \infty 00$ \\
\hline 3 & 30 & 0 & 60 & 15,500 & $930, \infty 00$ \\
\hline 4 & 30 & 0 & 60 & 12,700 & $T 62,000$ \\
\hline 6 & 0 & 0 & 90 & 10,900 & $981, \infty 00$ \\
\hline 11 & 30 & 0 & 330 & 7,300 & $2,409,000$ \\
\hline 35 & 30 & 0 & 1440 & 4,500 & $6.480,000$ \\
\hline & & & & TOTAL & $16,900, \infty 00$ \\
\hline
\end{tabular}

- Warmal operation for 30 nimutes prior to raliure. 


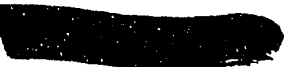

EN-30401 - V01. I -

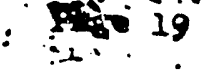

1.21 t Toere shall be suflctent flltered vater stored and avaliable to the reastor, whthout replenlshment from the raw vater sjstez, to proride 30 atnutes of process flov at 91,000 gallons per insute flas the rollowe required to satisfy the emergency trassition frae full flow to shutdow flow, plus 24 kours of shutdown flor.

\section{2aC neactor P1a1ng:}

The reastor pifilng shall be nodifled in such a maner that 91,000 8pon can be purped thrcugh the reactor by nine of the ten existias proceso punps wi-hour irrerloadlng their drtres by sore than ten persent of ibel: nameplatis harsepower.

\subsection{Disposal a: Reactor Breluent}

The reactor ersluent shall be retalned for an average time of not less than one tour before belag discharged ints the Columbia River.

\section{2to Instrimen:ation and Control}

All lastrigentation sball be of surpleient range ad strenfth to perfors the I I rastion inds: the coxditions resultios rom this program.

A prlmary system of reactor instrwencation shall be provlded ublch vill Instigate a "seram" if balling in an process tube becanes insinent.

A secondary systen of reactor lastrumeatation ball be provided which 112 "bachup" the primary sjoten to the extent that the 1maloence of boiling if ar process tube vill be detected 1ndependentiy of the func-

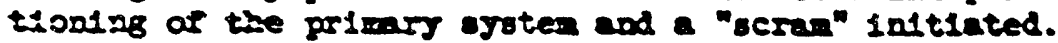

\section{$1.2 \bar{x}$ Cont1rucass Paison Colum Charging}

Salrable meckactam chall be provided to emable certain process tubes

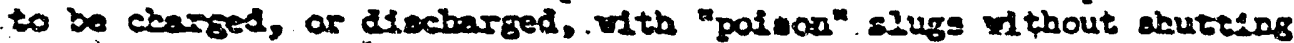

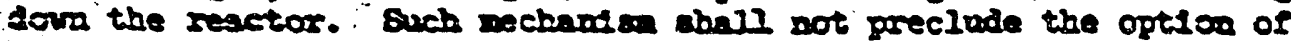

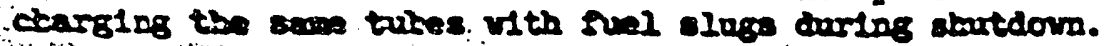

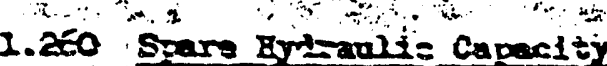

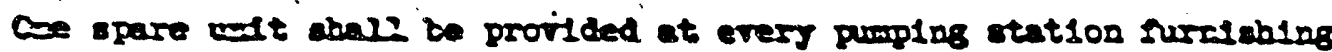
veter to the sliter plant or to process.

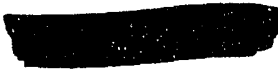




\section{DECLASSIFIED}

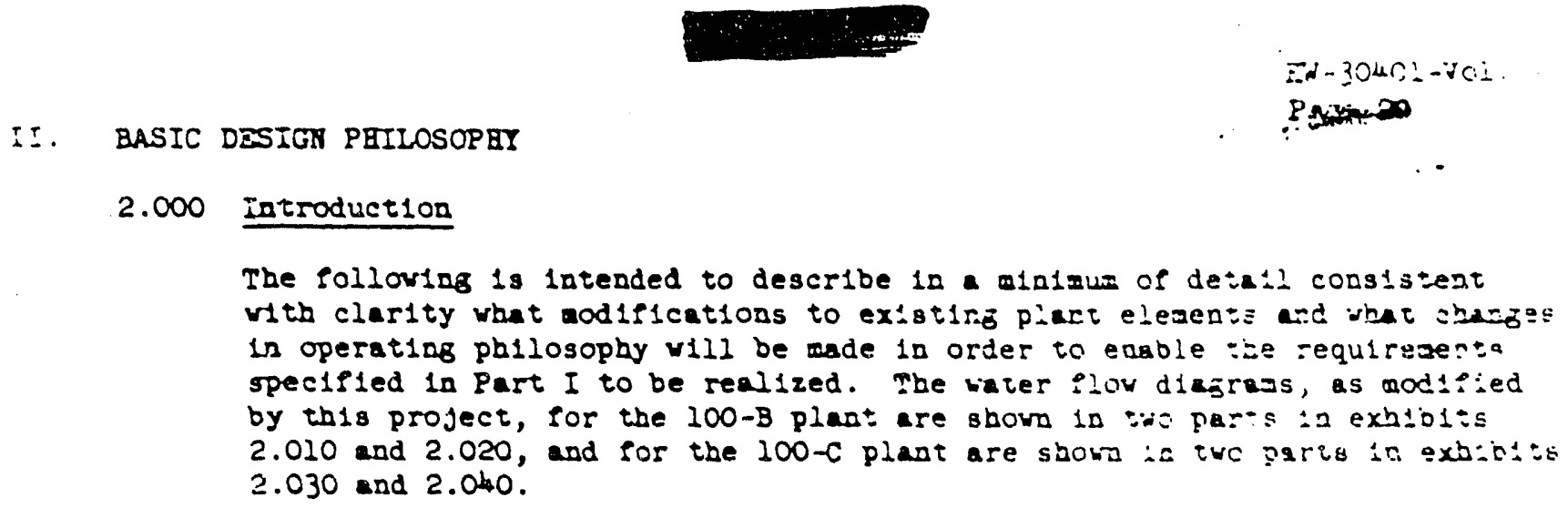

DECLASSIFIED 


\section{DECLASSIFIED}

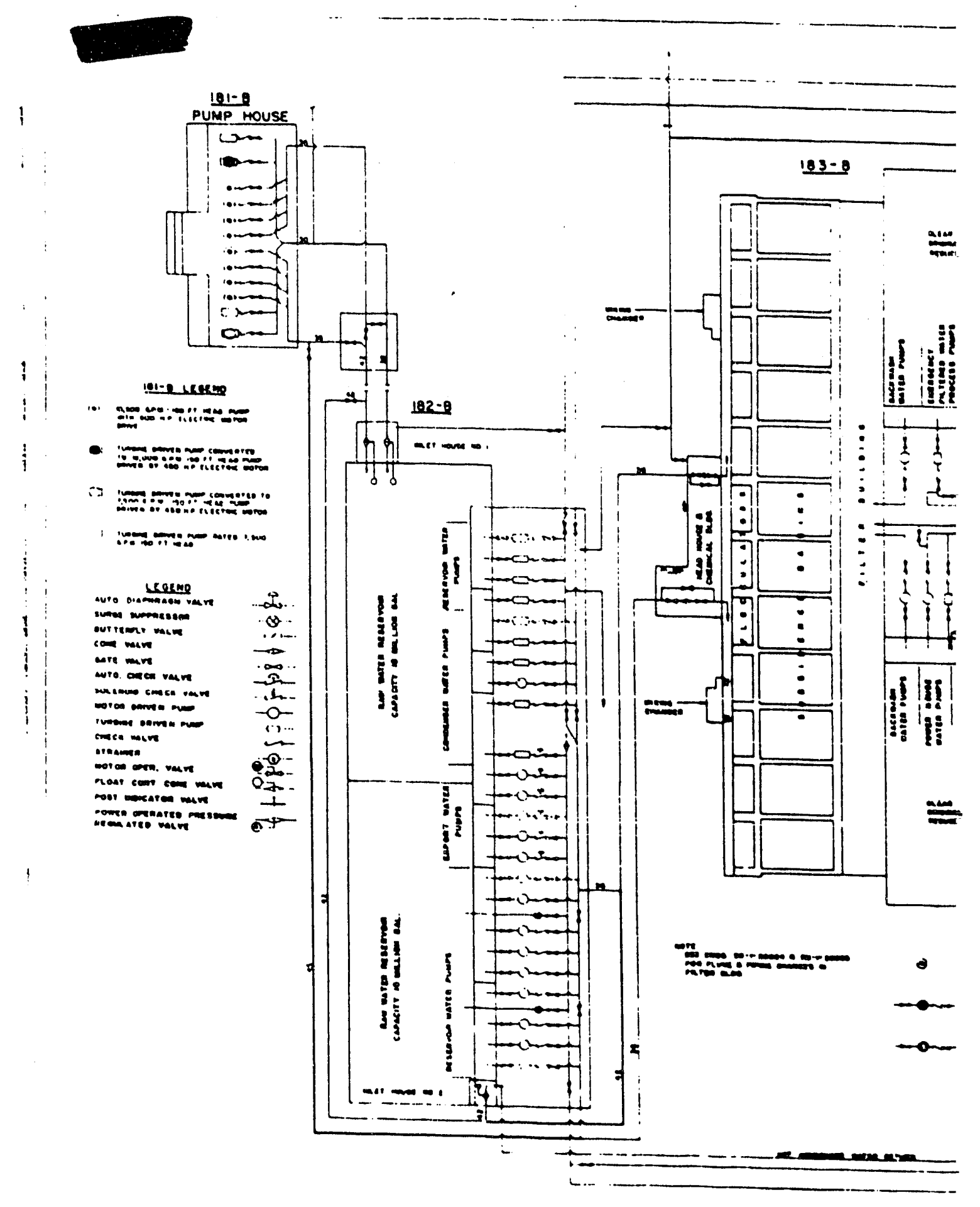




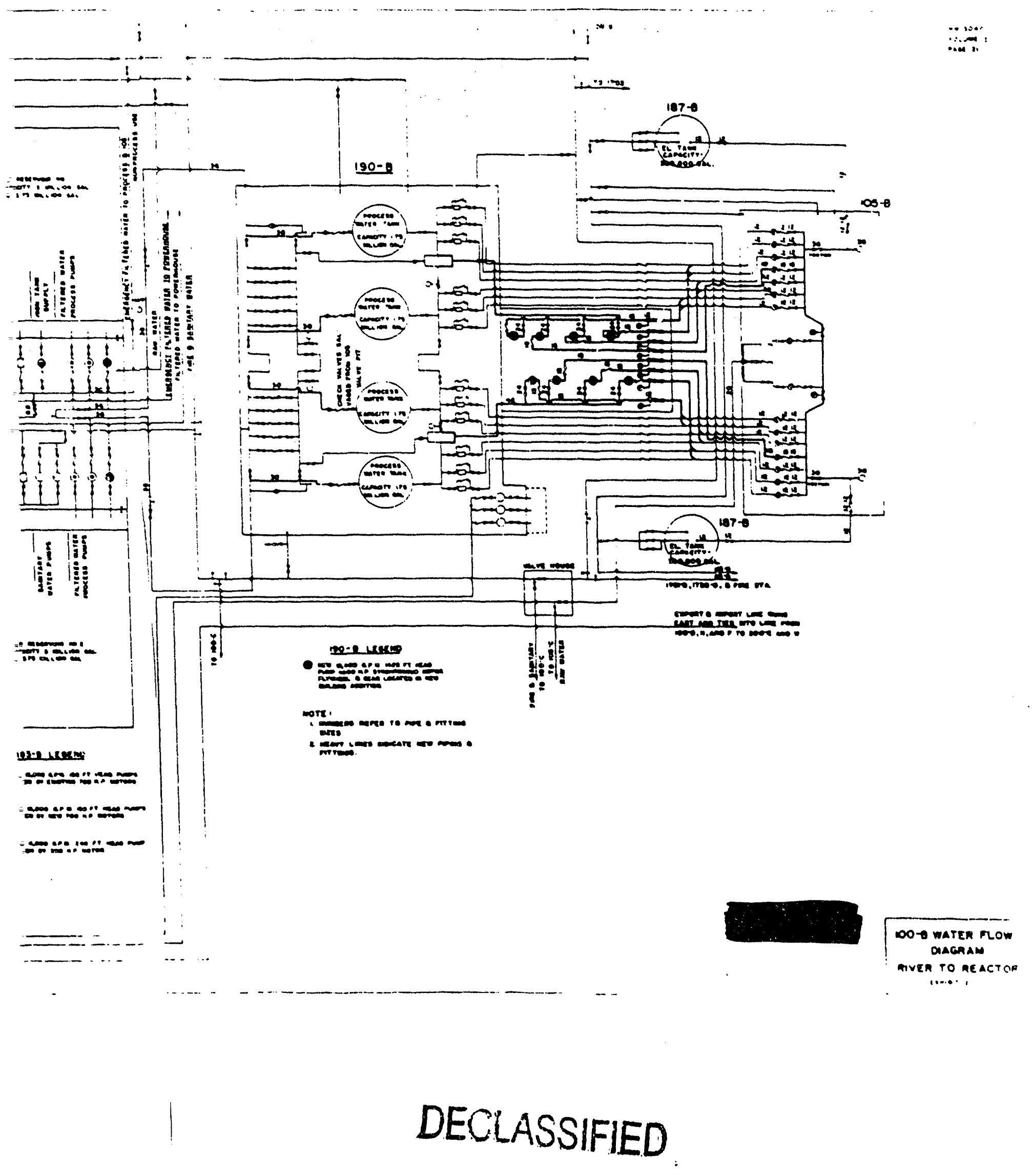


DECLASSIFIED

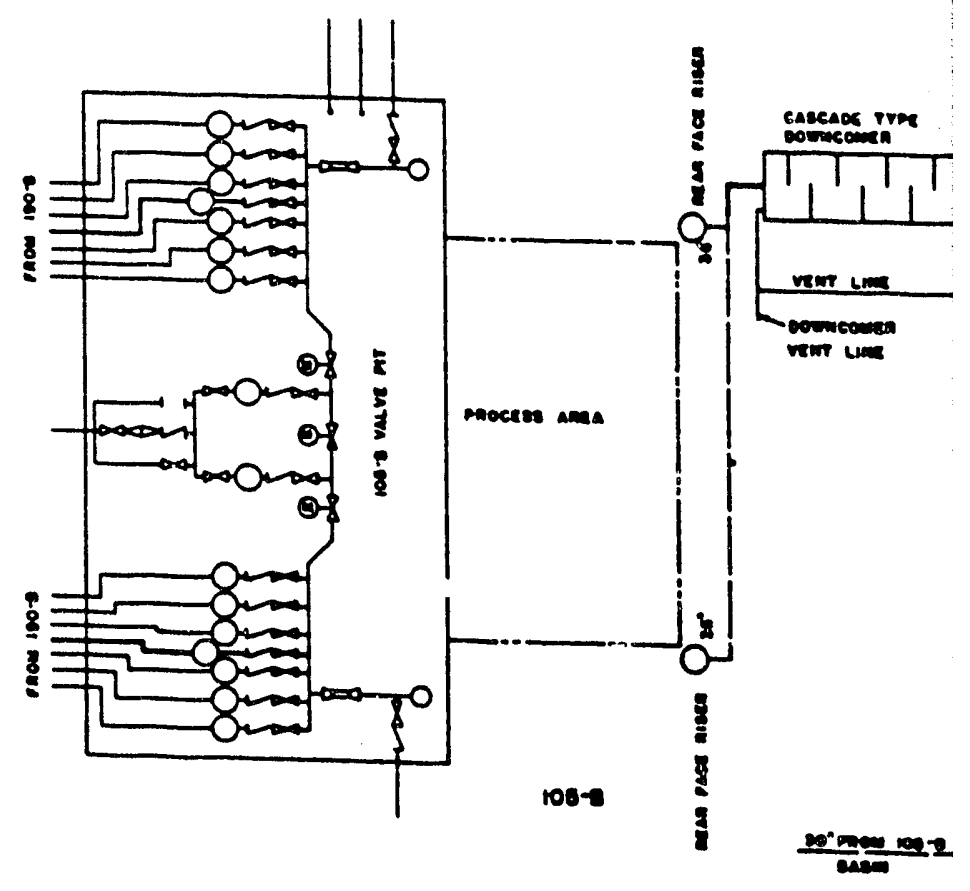


$\rightarrow:$ :

-ovuer:

-ace ua

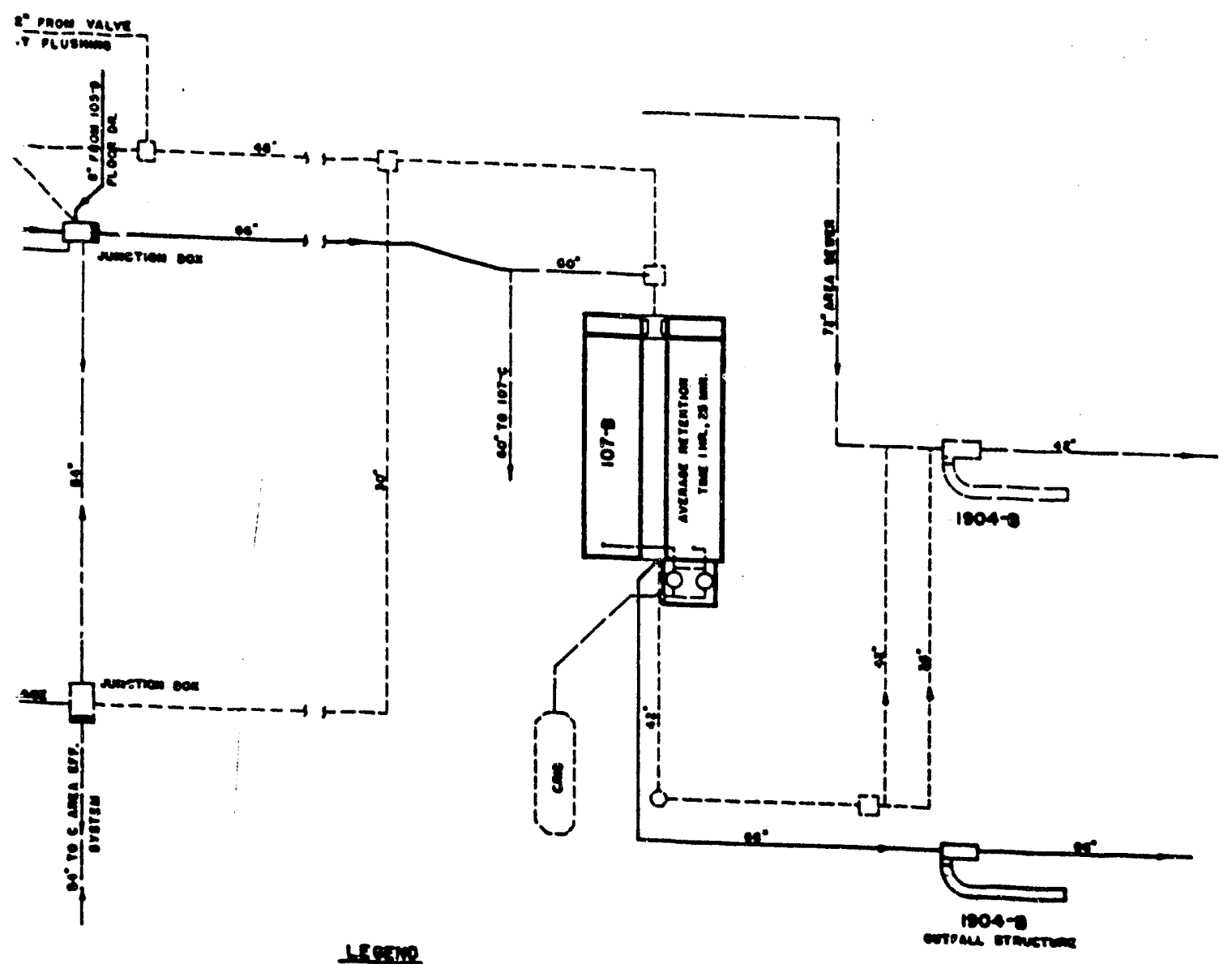

Leane

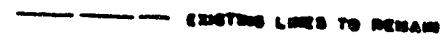

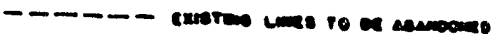

- ins

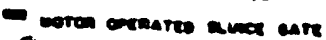

8 moren conver new

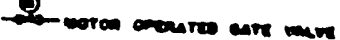

encerre remure

mosech nang

are montes

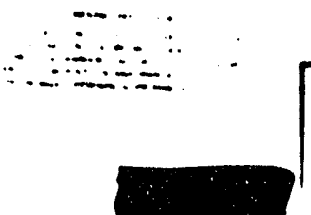




\section{DECLASSIFIED}

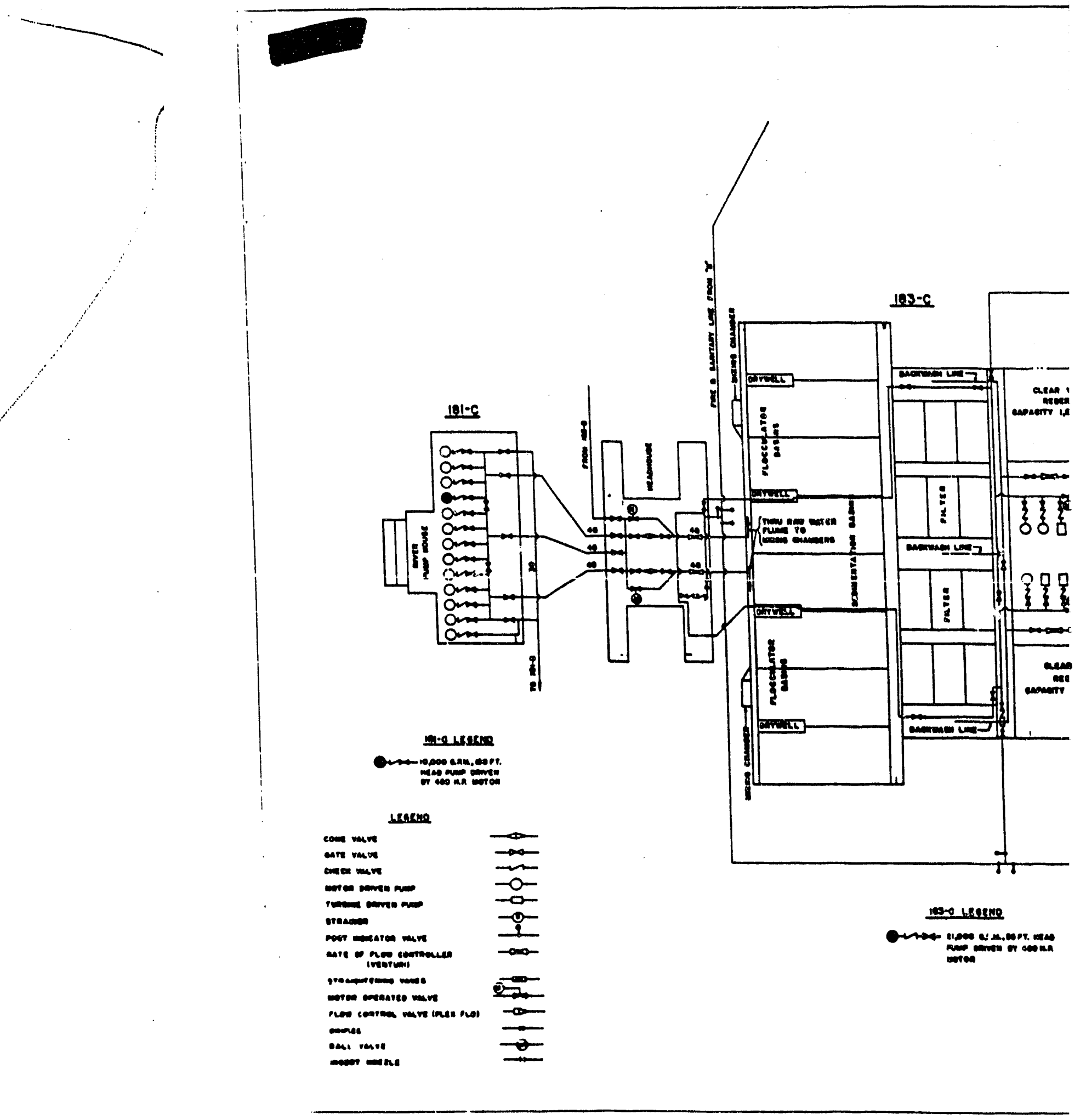




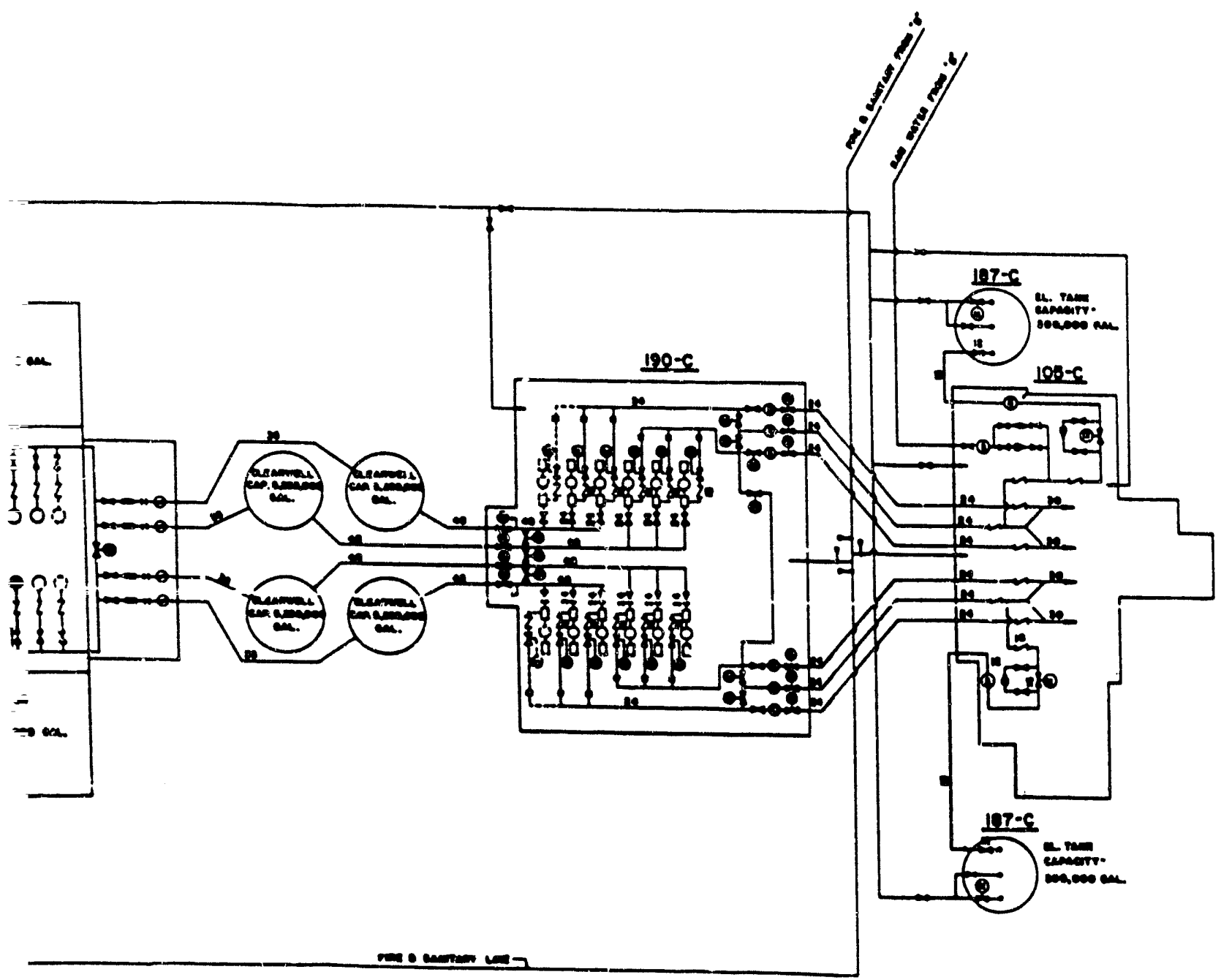




\section{DECLASSIFIED}

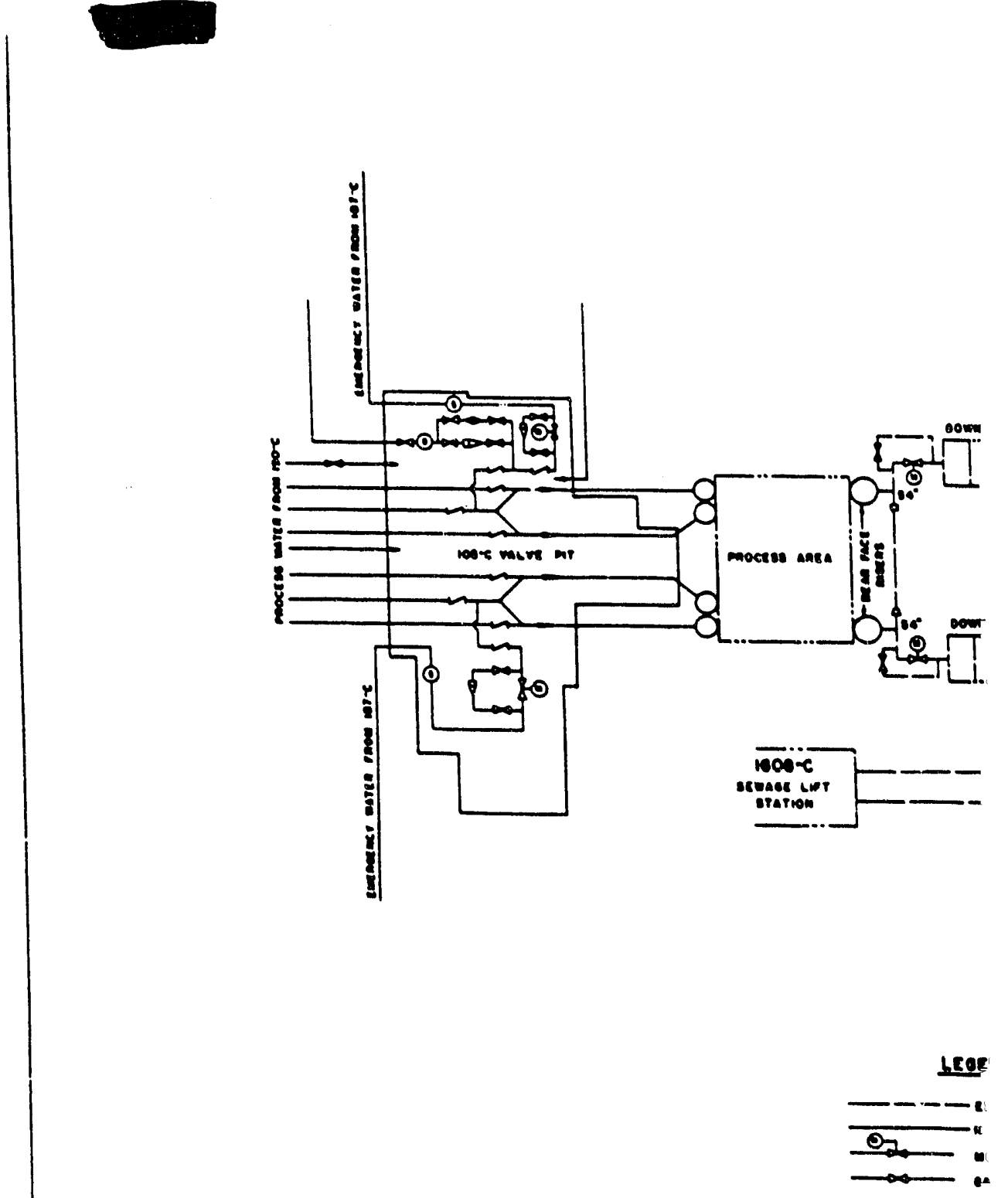


$\because \ldots$

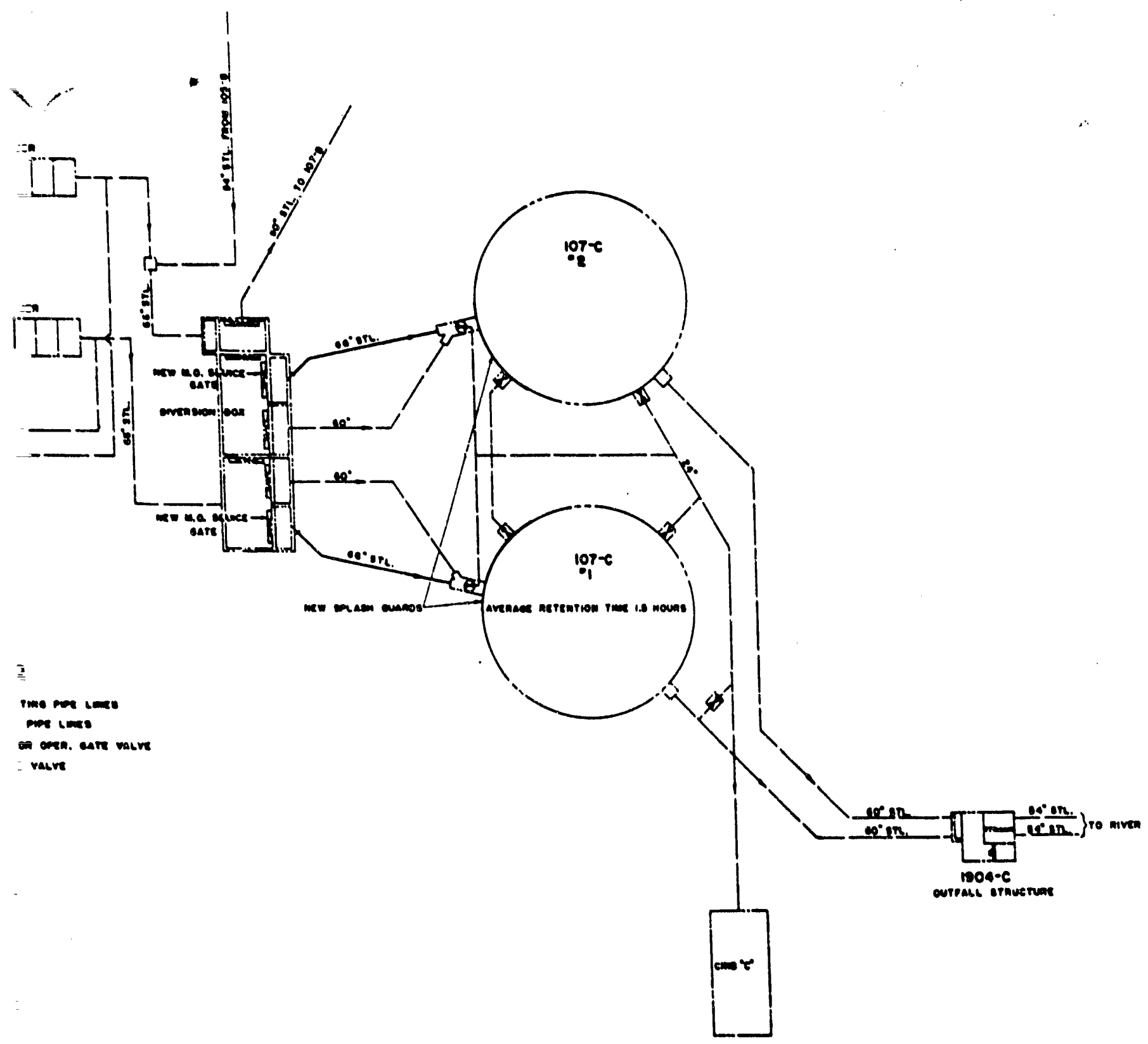




\section{DECLASSIFIED}

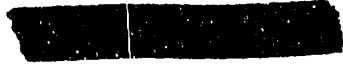

Exi-30401-V01. :-

Prge is

$2.100 \quad 100-$ B Area

\subsection{Resctor Mod1ficat1ons}

2.11] Pront Face P1p108

The lacrease in top of riser pressure, over that nov in effect. v1ll necessitate the replacement of the front face risers, lacluding the bese elbows.

Accordingly, the four existing atalaless steel risers of 20 Inch dianeter $\mathbf{1 1 1}$ be replaced $r$ th two carbon sted risers of heavier vali thlokness and 36 lach diaceter. The two risers of greater diameter $v 111$ be more efficlent hydraul1cally than the four of sanller dlaneter and $v 111$ be $1888^{\circ} x-$ pensive to install.

The existing four loch diameter etrminers at each end of each crosshender v111 be replaced with Plve inch otralners of the type used in $105-X$, in order to reduce head 2083 .

Fire lach check valves vili be installed at the ead of each crossheader in order to protect afalast the possible effects of boub blast or earthquire.

All front face nozzles and p1gtalls rill be replaced with a type of greeter bydrulle efflelency.

\subsection{Inetrumentat100}

\subsection{Tube Pressure Monstor1ng}

The installation of nev nosiles and pletello requires thet new reptur1 tubes in the central porer zone and new orfflces in the -frlage pover rone be lastalled to provlde the optiara pressuri and sensitirlty of response or the panelilt cages in the pressure nonstor systea. 


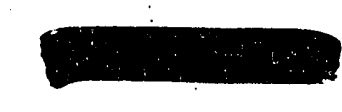

$$
\text { Ese } 20
$$

The existing Panell1t gages vill be feplaced $\because: t$. nir gajes of a similar but improved type.

A new and complete Paneli1t presoure monitor aystem w112 be installed in parallel with the existing systea for tho purpose of gaining the safety tiset a dial system vill afford. Facillties will be previded to calibrnte and test the individual Panellit gages in theis normal locations with the reactor in operatilin to provide increased oystem reliablilty.

\subsection{B10loglcal Sh1eld Temperature Mon1tor $1 \mathrm{ng}$}

It 18 anticlpated that the Inner mascnite layers of the blologlcal shield will gradually detertorate as a result of the beat generated by porer levels produced by this program. In arder to achleve a balance between maximum porer levels and reasomable shield life it will se necessary to control the rate of shield detericration. Th1s control will be accouplished by the installation of a temperature monitoring system.

The temperature monitoring system will consist of a serles of thermocouples loceted at selected positicns in the shield. Thermocouple reading will be registered at a central control polnt. The temperature will be monltored at the following locations.

Far Shleld: (2) Near the three coordinate centerI1nes of the shlelds in each layer of steel; (2) on the same horisontal axis as (1) but ix to elght feat farther torard the rear of the reactor and in eech laver of eteel; (3) On the same rertical axis es (1) but elght feet higher in elevation, and in each lajer of steel.

Top Shleld: (1) Near the 1atersect1on of the three coordinote centerlines or this shield, equidistant frow four central vertical rod plugs, and in Geh larer of steel.

\subsection{Thermal Sh1eld Flow Monttoring}

Rotating-rane, Ight-glass slov Indlcators vill be

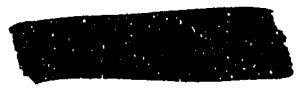




\section{DECLASSIFIED}

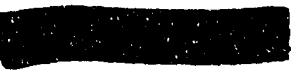

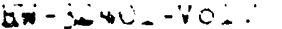

21

1

Iastalded between the thernal loop and each thermal shleld coollag tubs for the purpose of detecting flcW througt all tubes.

\subsection{Power Calculatson}

An autonetlc porer calculator systea vill be provided.

\subsection{Geoerd}

Al existing lastrumentation vhose ranges are exceeded by the conteuplated rater Hors, pressures, or opersting porer levels will be rebabllitated or replaced.

\subsection{Polson Colum Charglag Mechans:a}

Trenty-four tubes rll be equipped rith ball valves on both the 1nlet and outlet noszles for the purpose of charging or discharging polson pleces during resctor operation. The rear face ball valves vill be resotely controlled by a hydraulic systen of maunlly-operated velres in the coatrol roon. Speclal inlet connectors will be provided inth integen ralres to prorde a blgh flow rate for Flubles polson from the tube and a low slow rate for coolins purposes. The froat face nozzles vill be adnptable to the conventlonal ruel charglas nechlne as vell as to the polan charelag eachlse.

The polson colum charging wehine rill consist of a tube epproximately three feet 2008 into which the polson pleces will be pleced with the lalet ball ralre closed. After the tube 18 closed the bell valve rill be opened and the pleces pushed into the tube vith a hrdraule plston. Blectrical lockouts will be prorlded for the " $\mathrm{C}$ " elevetor, one to be located in the control room and the other on the charglag achlog, to provent noverent of the elevator during charging.

\subsection{Forisontel Rods and rulnbles}

Iise new horiscontal rods, except for the rack sections, w11

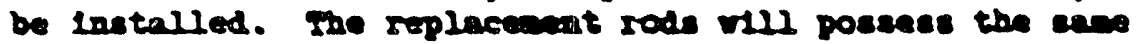
control abllits a the codstes rods bet illl have greater Plexib1lity, and heat transfer enpecity. 5tap vill be ane

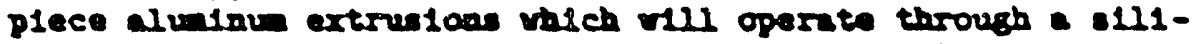
come seal pounted on the side anield. Thle oll ate possible the removel of expeting thibles wheh vill not runctios eat1sfactorlify at the teuperatures to be attalned at the bigher power levals.

The ald sbleld gates over the rod opandoge ill be renored and shleld plugs used then a rod is renoved from an opening.

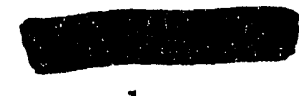




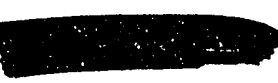

$$
\text { Fuse }: 99
$$

These plugs w1ll be stored in a shlelilag storage pit when nct in use. A leak detection system ut1lizing existing shield gate control lines as saffer lines wll be prorlded for the detection of rod seal leaks.

\subsection{Dorncomers}

The existing downcaner will be 1nadequat - to carry the contemplated flows, witbout entralment of air by the falling water and consequent Fibration due to the introdintion of sutatwospheric pressures vithin the plpe coivw:.

Purthe:, the ex1st108 cushion chanber and Junction box at the base of the dowacomer will become pressurlzed with the 1acreased flows, with consequent ieakage and intratuction of water and rapor 1nto the 105-B Buslding proper.

These conditions wil be alleviated by the remoral of the exiating downcomer and the 1nstallation of a "Cascade" tjpa of downcomer simflar to the ones presently installed in iosDi, 105-B and 105-C. The base of the dowacomer w11 rest is the present cushlon chamber at the $-2010^{\prime \prime}$ elevation. A $66^{\prime}$ effluent Ilne w1l be brought out from the base of the downcomer through that portion of the cusbion chamber at $-20^{\prime} 0^{\circ}$. The remalnder of the cushion chamber wil be abandoned.

\subsection{Process Water Syctem}

\subsection{Process Hater P1p1ns}

The 1acrease in water pressure over that now in effect wll neceseitate the replacement of the maln beaders in the valre p1t. The malas connecting the process water pumps to the adequate tructuplns connecting the export system w1I be Ing indlcates that 5 . An analjsis of the econconles of puaprace risers that the process water plplag between the front replaced wt th pipe of headers in the valve plt should be capac1ty.

Accordingly, the four exlsting stalnless steel pipes of 20 Inch diameter connecting the wain beaders to the risers vill be replaced with two 36 inch carbon oteel lines with required headers will be repine two stalaless ateel 20 1nch maln header of heavier mall thich a alagle 36 inch carbon steel

Tro new 18 lnch dameter process vater lines conplete vith relres and stralners vould supplement the 12 extst1ng libes p1t.
congecting the process pumps to the maln beader in the raln
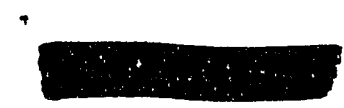


\section{DECLASSIFIED}

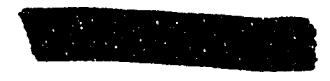

Exi-304Ci-VO...

Page 29

\subsection{Process Hater Puiplng}

The presently installed process vater pumplos lac1l1t1es cossist of 12 pueplag units. Each unit cons18ts of two pumps secondary. Bach puriven primary, and an electrically driven feet total head, at the 18 rated at 3000 8pm against 915 Tae modification will replace the existing 12 secondary pro-
cess pump with e1ght electrically driven maln process purps which wll in themselves be capable of developing the required bullding addition to These pumps will be located in a now process present 190 Bulld1ag. Bach main process pump w11l deliver 10,400 spa agalast 1360 feet TDH. Corsequently, the contemplated flow of $71,000 \mathrm{gpm}$ can be rding one spare unit. the elght maln process pumps, thus pro-

Th. existing steam driven primary pumpo vill be retained as emergency auxillaries.

In order to effect safely the transition from noran to shutdown flow, the drive essembly of the and process pump will contain a Plywheel. The lnertia of the assembly will of the main in the event of a BPA pow rate of dace puaps w11l decay at a rate that w11 produce a rate of decay of top of riser pressure slowe: than the olnileast 35 seconds. 11 lustrated on 1 ten 1.1131 for a period of

At such time as the effect of the fiymeels becomes insufficlent to malatain a pressure, at the maln pump discharges, blgher than that at the auxiliary pump discharges, check valves vill open allowing the auxlilery pumps to pump directly to the reactor bypassing the na1n pumpe. Onder these conditions. the steam turbines driving the auxillary pumps w1l bave been acselerated to a constant speed that rould cause ten or more of then to deliver flor in excess of the 35,000 spo required.

The characterletic of the plping systen through valch the prosess pump discharge vill be lightly influenced by fliming of the tubes and change in vater tempereture from aumer to vister. The effect of this will necessitate soes means of controlling Panellit pressure vithin the linlts of the trip sett128. Th1s pressure control vill be accoupliabed by 1nstalling a presaure regulating ralro et each pump discharge.

2.123 Sol1ds Feed Syeren

The present solids feed syten consists of alxiag tanks, tracsfer purps, 1nject10n punps, and etrainere for injecting - If diatomseour earth surry lato the procese vetor otrosa.

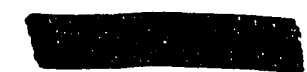




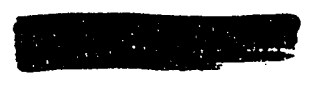

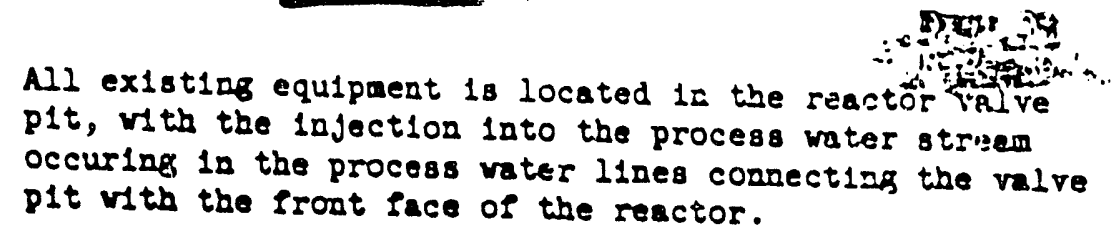

The existing pumps and plping are inadequsts to supply the required amounts of diatomaceous earth slurry required under thl progran. All existing equipment, with the exceptlon of the 11,500 Bal. mlxiag tank, will be rewored and roplaced with a rew system.

Two new pumps will be lastalled, taking thelr suction directly froa the sollds feed mising tank, euch capuble of dellvering 200 spa of a $5 \%$ diatomaceous earth slurry at a rated bead of 640 psi. One pump 1s capable of supplyIng the required amount of slurry for a purge of the reactor pipling. A power operated self cleaning type of stralner will be prorlded in the suction line of each pump to provide for atraining of the slurry. Provision for injection of the lurry shall be made in the valve plt plping.

The present solids feed system 18 also used as source of ifgh pressure 11ltered water for tube rlushing. Provision vill be made for the continuance of th1s vater supply.

\subsection{Flitered Hater 8ystem}

\subsection{Water Ireatment}

Water quality of the required speciflcation $\mathrm{Wlll}$ be ettained by treetwent with alum and activated sillca as presented in document EN-29542 which out.l1nes the licope of Project $c 0-567$ ent1tled Num-Act1rated 8111ca Water Treatment Pac1l1ty.

\subsection{F11ter Plant}

The hydraulic capacity of the fllter plant w1ll be 1ncreased ouffleleatis to oupport the followlng deands:

To process
Bon-process to 105-B
M1ecellaneous
To 190-8 (cooling)
8ubtotal
Tilter backrash
Total

$$
\begin{aligned}
& 71,000 \text { 6pa } \\
& 4,000 \text { Epa } \\
& 1,500 \text { spo } \\
& 1,500 \text { spa } \\
& 78,000 \text { gpa }
\end{aligned}
$$$$
\text { 4,000 gpe }
$$$$
\text { 82,000 8pa }
$$

The required increase in hylraulle capacity wll be eccoeplished by mane of alterations vales vili laciude the foifovita

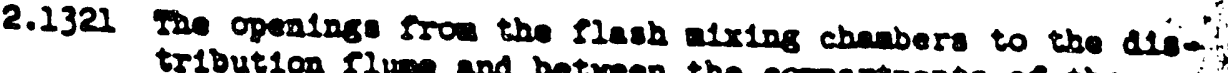 trlbut10n Slume and betwen the coppertanents of the alxior charber vill be ealarged.}


2.132 .2 The discharge capacity of the systed conveying vater from the subsidence basins to the fliter bede $w 11$ be increased by plercing the wall between the subsidence basin outlet flume and the fliter influent flume with aeries of boles two reet square.

$2.132 j$ The present f11ter medie of 10 1nches of anthraf1lt, 20 1nches of sand, and 12 1nches of gravel w1l be replaced with 27 inches of anthraf1lt, 3 Inches of sand, and 12 inches of gravel.

2.1324 The head 10898 through the f1lter effluent flume w1ll be decreased by removing an orlfice and baffle presently installed in the flume.

2.1325 The avallable bead across the f1lter beds $w 111$ be Increased by lowering the clearwater reservolr ourface by twc feet.

2.j.jé Fifier fiow controis wili bs redesigned to operate at rate of $71,000 \mathrm{gpm}$ to the resctor.

A syster w11l be provided so that the effluent from each f1lter may be automatically sampled at the head bouse laboratory.

The system will consiat of two sampling punps, one for ench

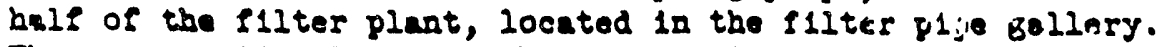
The pump suction line vill be a malfuld lalo which copper tublis bas been connected from each fliter effluent ilne. Throem say olenold operated valves vill be located in each sampling line so that a contlauous flow of vater through the 11nss vill be malatalned at all t1mes, e1ther to rasto or to the sempling pump suction. Controls for the pumps and valves w1l be located in the bead house so that the 11 ter to be sarogled may be selected at that polnt.

The valve control vill be arranged so that one sampling IIne to each puwp way alrays be open, thus lasuring constant flov of semple vater. A Q1scharge line from each pump wII be run to a supliag int located in the head bouse.

\subsection{Filtered Wator rumplag}

Present: $:$, flitered meter for noran process requalremenss 1. pumped from the s1lter plent by eloctricaly distan pumpe. Hormally connected to the prosess vater 2009 are brancbes to the elevatad tanks $(187-8)$, theran shield cool1as, basin cherging, and to the boed bouse for alscellencous services. Parallel to this eycted it a omergency ayetem onrved oy tean drivan pumpo.

Under thia project rill be lactalled an electriceldy driven pump of $4000 \mathrm{gra}$ capacity ralch w11 rua continuously to 


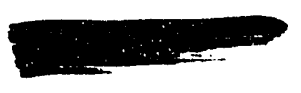

$$
\therefore \text { is: } 32
$$

furnlsh thermal obleld coolizg vater, whter for alsceliencous fliter plant ervices, and ralch could firatsb a contlauous fow through the elevated tacks and through the storage basin, 19 and when desired.

Relleved of the head requiremats of the olevatad tanks and thermal loop, the four presently lastalled flitered re tor pumps would be required to develop approxtantely $50 \%$ o: the bead now raquired. These pumps would then operate at or near their cut-ce: poiat ond at a freatily roduced esi-1elency. Consequently, whsy vill be replaced hy pumps at the head required $15,0 \mathrm{O}$ spz each. Tils dischargo

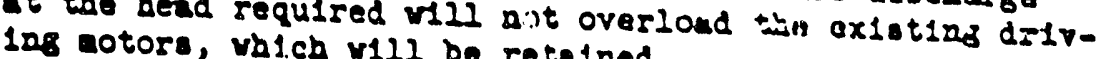

The balunce of the $72,500 \mathrm{spm}$ requirement, plus one spers ualt, v1ll be ruralobed by installing two new 15,000 epa

\subsection{F11tered Water P1pe I1nes}

Preaently, s1ltered rater 1s pumped to the slearvell tanks, 1n 190-B, through ten 11nes feeding from a loop. Each Ilne contalns a butterfly valve and orfflic. The present cyctem requires these energy d1so1pat1as devices becausethe slitured vater pumpe must develop a pressice much greater than that required to supply the clearnello.

The hlgh preseure eerrices w11l now be supplied by the oplesete bigh preseure pirp. Consequently, the ralres and":

2.135 F11tered Vater storage

Of the $10,907,000$ gellone required to ent1sfy the criterli Jater. tated In paragraph 1.214 ceven m1l110n gallons are arailail In the 190-B proceses reter tant arabiule.

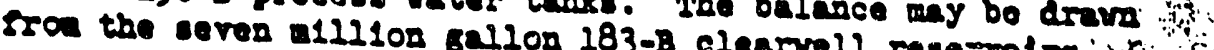

\subsection{Rex Nater gyeten}

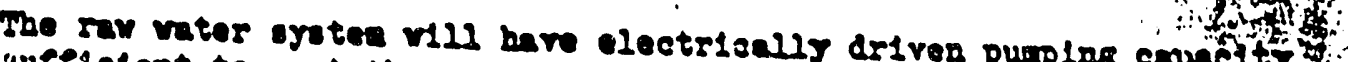

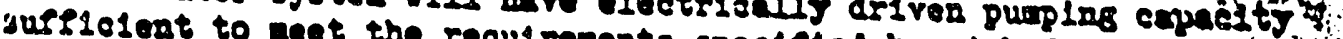

20 183-8

20 Export
$82,000 \mathrm{spe}$ $18,000 \mathrm{spa}$ 100,000

sotal

\section{0,000 con}

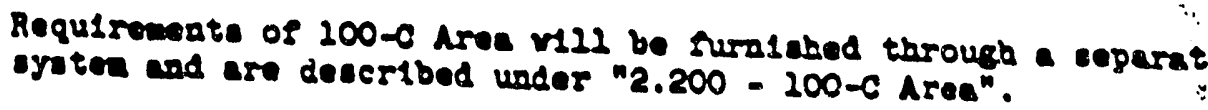

In furaleblas the requirs flom proceat node of operstion.

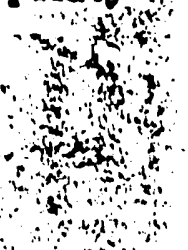
ato and

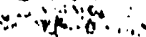
sin Sros the i... 


\section{DECLASSIFIED}

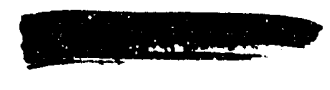

Exi-30401-i2:. 1

Page 33

The presently installed raw water system provides two parallel pumpling systeins between the river pump house $\left(181-B_{\text {a }}\right.$ and the rav vater reservolr $(182-B)$.

One yoter 10 werved by elx electrically driven pump pumpins into a 42 lach line to the reservo15. The otber system 1s served by three stean driven pumps and two electricaldy driven pumpe pumplng into a 30 inch ilne to the reservolr. The two systeas are cross-connected near the river pump bouse.

All water to the s1lter plant 18 presently pumped from the raw vater reservolr $(182-B)$ to the hoad bouse $(183-B)$.

The changes contemplated under th1s program v111 provide one pumplng and plplas eystem for export, and other raw vater demand, and another eysted for eupply1ng water to the head house. Th1: 1111 Involve ealarglng and lacreasing the efflelency of the system pre. sently suraleblag rater to the bead bouse. Spec1flcally:

Fion wouid be diverted around the rav veter reservols, through the exleting systen, directly lato one olde of the head bouse; ar $48:=5$ : $1:=5$ wist te 1nctalled from the rlver pump bouse directly Into the oppositn side of the bead house.

All exlsting raw vater lines would continue to be Interconnected naer the river pump house and rould eacb be capable of pumplng independently lato the raw vater reservolr.

At the river punp house, the $\$ 1 \times 10,000 \mathrm{6pm}$ unlts presently furn18h1ng veter for f1ltrat1on and for export will be ropleced with ix 10,5000 span units puwping directly to the bead bouse. A seventh and elehth $10,500 \mathrm{ggm}$ undt vill be added to the eyseter.

Hater for export, and otber ray veter demand, w111 contlaue to be furnlobed to the raw mater reservols vis the exletsas 30 Inch plpe 11ne.

To provlde apare electricelly driven capeclty, one of the thrae

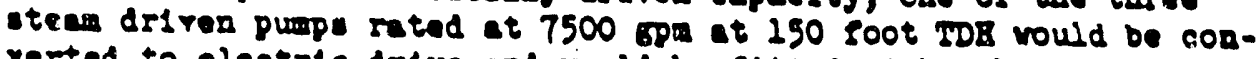
rerted to electrio drive and vould be eltted with a bowl and $1 \mathrm{mo}$ pelier assombly to lacrease 1to capecity to $10,000 \mathrm{cpm}$ at 150 foot

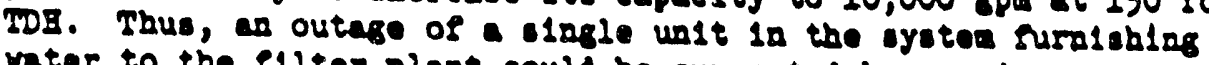
weter to the eliter plent could bo oupported by purpling extre vater to $182-\mathrm{B}$ and theace to $183-\mathrm{B}$.

\subsection{0 slectrle Power 8upply}

A normal 1acrement of 20,000 kre orer the present deanad of approx 1 antely $15,000 \mathrm{kra} v 111$ be required by 100-1 Area under thls progrem. 

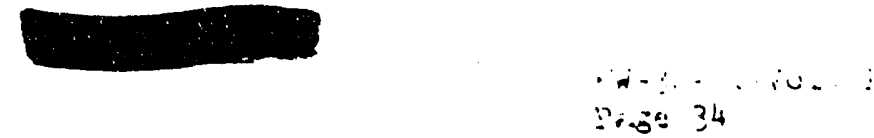

Th1. 35,000 kve w111 be dram from the mod1fled $230 \mathrm{k}$ trassu10s100 oysted ris the 151-B substation as it now exists.

The 27,500 kra normally requ1red by the process puap drivas, in the 190-B Bulld1ng, w1ll be transmltted directly to the wotors at 13.8 kv via nev clrcult breakers and underground cables.

An edditionsl lacrecent of $1300 \mathrm{kva}$ wild be requlrec by the river pump drives and v1ll be transmitted, es present.ly, at $13.8 \mathrm{kv}$. The added 1ncrement of power w111 necessitate naw $13.8 / 2.3 \mathrm{kv}$, 5000 kva substation at the pump bouse.

All otber electrical pover requirements w11l be setiofied as at present.

\subsection{8toum Qeneration and Ut1112at1on}

The effect of th1s progrio upon the stem demand of 1CO-B Area w1Il be to greatly decrease the base load on the steam gunerators, and to greatly eccelerate the rate of stens demand durlap the in:tinl - tage of en emergency BPA pover outago.

Th1. change in the steam ut1lization frow that now in offect is Que ent1rely to the change in operation of the 190-y process pumpIng station, dascribed under paragraph 2.l'i2. Ciler require-

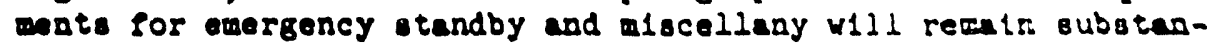
t1ally the same as at present.

The present bese steen demand of the turblace driviag the 190-B primary process pumpe is 120,000 pourds per bour and represects approximately 70 percent of the thtal steus ganerated exclualve of that for bullding beating. After the accomplistrent of ihis program, the base steam demand of tho turblaes drivint the auxiliery procese pumps vould be 20,000 pounds per bour or 28 percent of the total stean generated excluelve of that for bu12dins beet1ng.

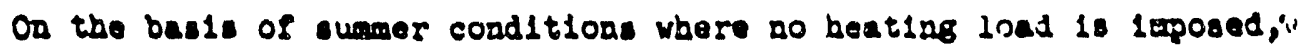
the base laed on the boller house vould be approxinstely 70,000 pounds per hour. The four bollers lastalled In the 184-B Bullalas are each rated at 100,000 pounds of stean per bour and rould require a elaluuin load of not less than 20,000 pounde per bour per boller in order to operate setlafactor1ly. Three bollers seamlas rould require a bese laad of at least 60,000 pounds per bour valed v112 be exceeded by 10,000 pounds per bour. H1ater conditlons rould necessitate the teuming of the fourth boller 10 order to oupport the bullding best1os demand.

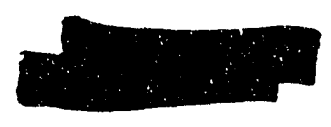




\title{
DECLASSIFIED
}

EN-3040i-10: 1

Page 35

\begin{abstract}
In the event of BPA pover fallure, the team oupply to the turbine driving the auxlilery process pumpe would be acceleratod frow 20,000 pounds per hour to 120,000 pounds per hour $v 1+h 1$ n 45 seconds. Th1s degree of acceleration 1s within the capab1l1ty of the boller and turblne response when four mlnute delays are 1ncorporated in the emergency switchicus to stean driven vent1lating fans in the reactor and gas bulld1ngs. Th1s delay in operation of the emeriency ventilating system vould not lacur unreasonable risk in reactor operation siace the possibllity of the colncldence of an electric porer fallure with a reactor contanination 1s low.

The above stated emergency stean demand is predicated on an operatiag procedure under valch no coollag vater vould bo furnished the condensors serving the auxiliary procest pump turb1nes. Operating non-condensing, the turbines would require about the same amount of tean under normal operating conditions as bey rould requiro if runalag condens1ng. Under emergency cond1tions, the Instantaneous stean denand to the turb1nes vould be 120,000 pounds per hour v1th non-condensing operation, as compared to an lastantaneous turblne deand of 95,000 pounds per hour, plus a demand of 6500 pounds per hour to the condensor water pumps vith process pump turbines operating condensing.
\end{abstract}

\subsection{P11e Erfluent system}

\subsection{Process Sever System}

The 1ncrease in the process veter flow rate 111 necessitate replacement of the ex18t1ng 48" RCP effluent I1ne between $105-B$ and $107-B$. The exlsting relaforced concrete pipe is not bydraulically capaole of bandling the vater Slows; and 18 in such a tate of physical deterlorat1on that 1t would be neceseary to replace the lover portion of the l1ne at the present process flows in the immediate future.

A diversion box vill be provided in the vicindty of the 105-B Bullding to provide crose connect1on with the 100-C effluent systea and to collect the 105-B Bu1lding ploor dralnaje. 


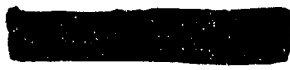

테-3040i-70i. 1

Page 36

\begin{abstract}
2.2T2 107-B Retant10a Basla
The retent1on besins are of surficlent size to retait the resctor effluent for a perlot la exiess of odo
\end{abstract} bour.

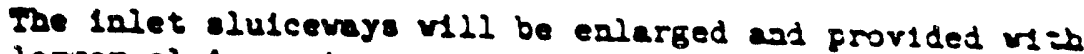
larger elulce gates.

The outlet velr vill be lowezed by one foos to prevese orer-topplas the besin.

Io changes in crib plp1ns, besin dralange systew, of erluent conltorlas sjotems are aecesens.

2.173 Outfall syotoe - 107-B to M1d-R1ror Cbarel

The existiog outfald gretan serves? th the $16 \%-8$ retention basin and the min area nevar eratom, as nans of disposing drelabte to the river. Jader the incroesed flow rates, the procese bavar lines frow 107-B to the outiall etructure, the outfald otruct ine $(1904-2)$ and the $42^{n}$ outfall ilne v111 to budrauliendy inadequate.

It 111 be adventageous to construct a capletely ast

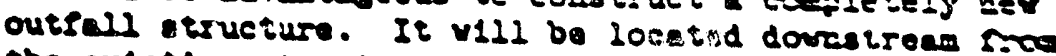
the exletias etructure. It will be coanecsed to $107-3$

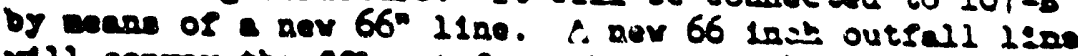
ill contey the selwent froe the new 1 got Bulidins to ad-river chanael.

All procese, and other retalaed dralange, v112 be discharged through the bu outfall eysted. outfald mll contlnue to serre the arou wio sever.

$2.200 \quad 100-C$ Aree

\title{
2.220 Reactor Modssicat1ons
}

2.211 Jroat Tace PIplas

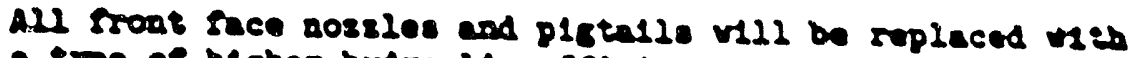
- ispe of hicher budrenlio efflelency.

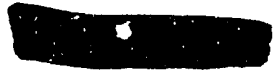




\section{DECLASSIFIED}
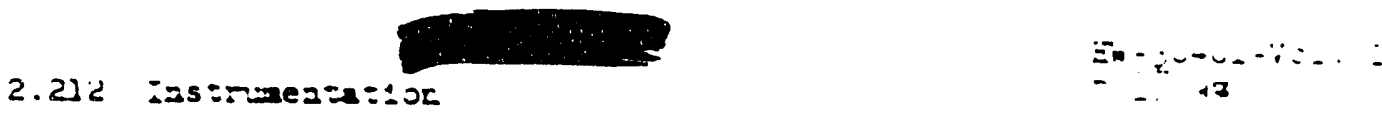

The lastallatlon of ars nozzles and plotalls requities thet existing reasurls is the central pover sone be roplaced vith dev reaturl tubes to provide the optirne proseurs and senaltivity of response to the Parellit gases in the preseure nodtor sgreas. Bs tapplas the Pasellit gages late the throet of the reaturl and thus reglotering a pressure less than the tube 10let prosente, the exlatiog Panellit geges vill ccotinue to be of edequate rance. Moreover, the sensitivity of response of the Pasellit syeten to and variations in pressure Fill be laproved.

Were nectucary, the existing oriflees in the fringe porer zone will be replaced with nev orlfices wach will produce

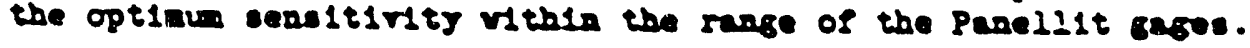

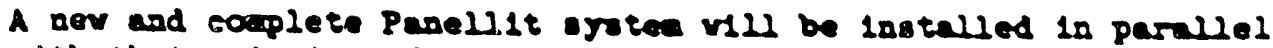
Ilth thet existing of the purpose of calning the sefety that - dund eysen wil areord.

Fac1l1ties rll be prorlded to cellbrete and test the 1adiridun

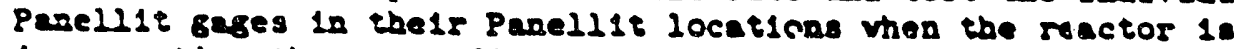
in operation thue providins lacreasud rellablisty.

Exleting 1netrunentetson, lncluding the eutontic porer celculator, the senl-eutomelc power celculator, and alscelleneous

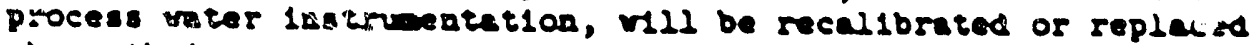
rh irs their ranges are exceeded by operetelng porrer levels, vetar slows, os pressures.

\subsection{J.3 Polson CC}

Trenty-fcur tubes v1l be equ1pped vith ball valves an both the lacet and outlet noszles fCr the purpose of charglag or dischnoglas polson pleces durlng reector operst100. The reer face ball valres vil be rasotely contralled by a brdraule - juten or naully-operated ralres is the control roon. Special lnlet connectors vill be provided vith lategral velves to proride a hich flow race for fluabling polson froe the sube and - lor flor rete for coolins purposes. The front face noseles

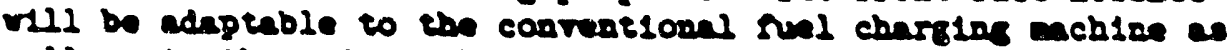

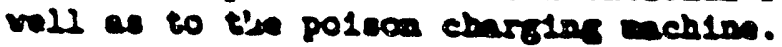

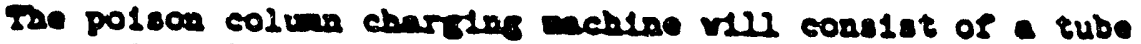

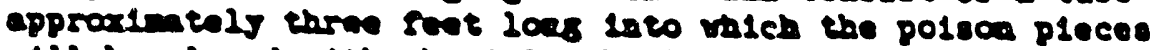

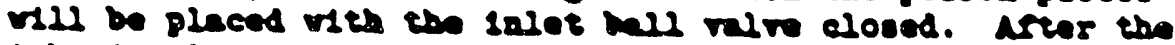
tube 10 eloced the bul ralv mil be opened and the pleces

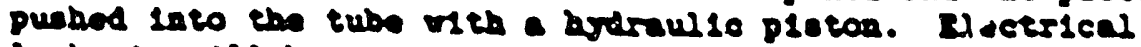
lockoute $\mathrm{HL}$ be provided for the "C" elevetor, ow to be loceted in the contral roo and the otber on the oburing nchlee, to prevent novinint of the elevecor during charging.

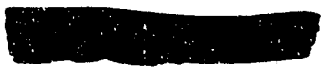




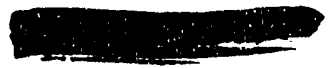

is. $-2 . \cdots$

\subsection{Process Water Syrter.}

The capacity of the procese vater system vill be increased to meet the requirements of this progran by decreasing the resistancs of the

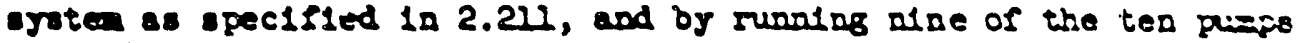
lostalled.

The phllosophy of operation vould remaln the same as curreut ly, except that the rated flov vould be on the basts of one rather thar tro epare pusps.

On these bases the d-1rins motors v1ll drav current 3x - $10 \% 10$ excese of that at uhich they are rated.

in the ereat as as energency sbutdown due to a BPA power fallire, the andmin allowable rate of decay of the rioer pressure will be that 11lustrated on exh1b1t 1.2131. The Ilywheel erfect of the existiog purp drive assemblies 1s ourficlent to wet this mquiremen:

\subsection{Mlterod Nater 8rstem}

\subsection{Water. Treatadnt}

Heter qualsty as the requered speciflcat1on w1ll be attaloed by treationt vith alum and act1rated allica as presented 1: Document Bin-29542.

\subsection{P1lter Plant}

Tho elltar plant vill be required to support the follovito demand:

$$
\begin{aligned}
& \text { To } 190-C \text { Process Plmpe } \\
& \text { Non-Process to 105-C } \\
& \text { Mlocellade ous } \\
& \text { Subtotal } \\
& \text { P1lter Backraeh } \\
& \text { sotal }
\end{aligned}
$$

$$
\begin{array}{r}
91,000 \mathrm{gpm} \\
4,000 \mathrm{gpm} \\
1,500 \mathrm{gpm} \\
\frac{1}{96,500 \mathrm{gpm}} \\
4,500 \mathrm{gpm} \\
101,000 \mathrm{gpm}
\end{array}
$$

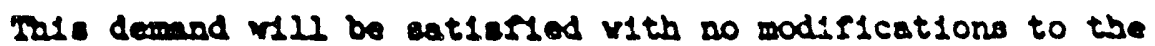
Sliter plant.

\subsection{Flterad Inter Pumplos}

The pupios capacity of s1ltered vater to the process vater clearmille and to buckneh vill be 1 pereased to meet the requlremote of this progran by addeng ane nev rert1cal tur-

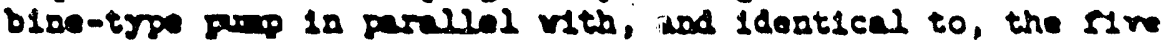
21,000 op undte prosedtis lostalled.

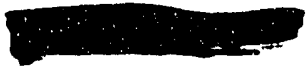




\section{DECIASSIFIED}

\subsection{Rav Water Syotem}

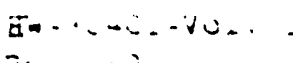

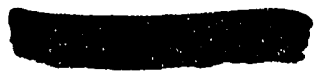

$=4$ : :

The rav vater suppls to $100-C$ Area rll, as at present, under normal opertins cond1tions be punped from the river pump house (181-B) directlo to the 183-C bead bouse.

In order to provlde the required 101,000 oullow per marte of rav vater, one nev river pump will be lastalled in parallel with, and Identscal to, the ten untes presently installed.

Th1s Installed capacity w1l prorlde, In addition to the pumpo required to ruratsh $101,000 \mathrm{Bgm}$ to 183-C, a sare unt capable of pumplng elther 1nto the $100-C$ ray vater system or 1 to the 100-B raw water system as descrlbed under paragraph 2.140.

\subsection{Slectric Pover Supply}

An incrament of $800 \mathrm{kra}$ over the present demand of appraximateds $34,000 \mathrm{kva}$ will be required by $100 \mathrm{ma}$ Area under this progrum.

Th1s 800 kva wall be drewa fran the modtfled $230 \mathrm{kr}$ transmlssion

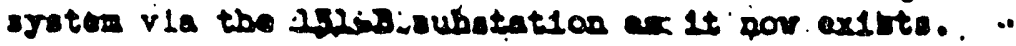

No addftonal transformex or oultchgear capaclty wll be required to aerve additlonal power demand by 100-C plant.

\subsection{Steam Genurat1on and Ut121zat1on}

2h18 program vill bave no olonlflcant effect upon the otean deand of 100-C Area.

The cafactity and capab1lity of reaponse of the existing boller plant $v 1$ il be surficlent to provide the requirements of $100-C$ Area when comblned witb 100-B Area as described under paragraph 2.160.

\subsection{Reactor Brelueat Syetem}

\subsection{Process Sever System}

The changes to th1s sytem are based upan a future possible procese flow of 100,000 spm attalnable by 10 stalling procese vater pumpe in the tro racant places in 190-C.

On this besis the follorlog changes to the effluent syctem ill be ande:

In the diversion box, the "Xoock-out mus" between the nat chamber and the outlet chambers vould be removed and oev motor operated alusce gates intalled. 


\subsection{7-C Retent1on Basin}

A splash guard will be provided at the influent to the basin in order to prevent oplashing over the basid walls.

The tro exist1ng 66 1uch pipe connect10:2s at ine

bax would be connected vith 66 lach pipe to extsting to lach connectlons at the 107-C basins, each bax cunnest1ng to 1 ts respect1ve basin. 

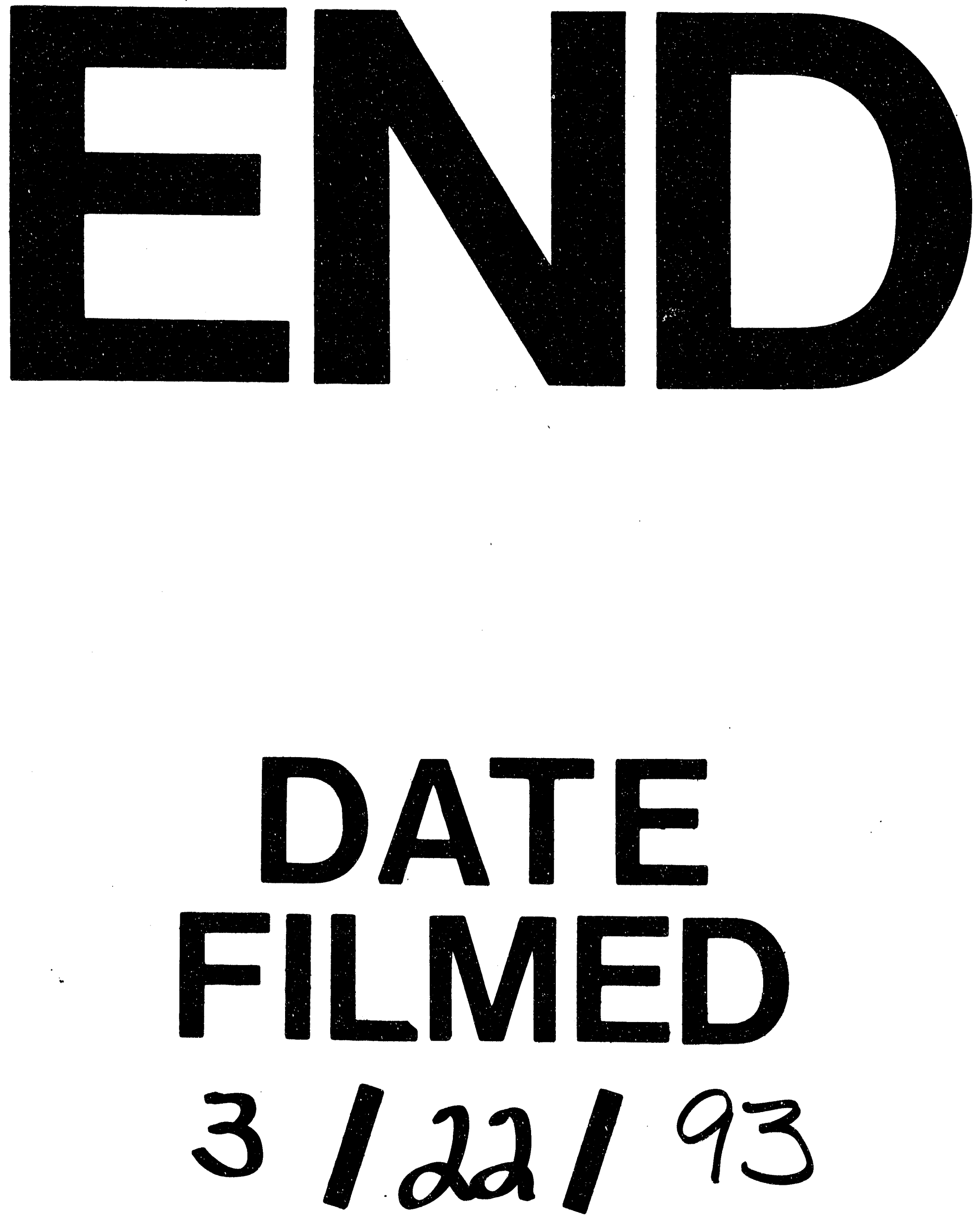

1 
